\title{
The Segregated Intestinal Flow Model (SFM) for Drug Absorption and Drug Metabolism: Implications on Intestinal and Liver Metabolism and Drug-Drug Interactions
}

\author{
K. Sandy Pang *, H. Benson Peng and Keumhan Noh \\ Leslie Dan Faculty of Pharmacy, University of Toronto, Toronto, ON M5S 3M2, Canada; \\ hao.peng@mail.utoronto.ca (H.B.P.); keumhan.noh@utoronto.ca (K.N.) \\ * Correspondence: ks.pang@utoronto.ca; Tel.: +1-416-978-6164
}

Received: 12 March 2020; Accepted: 27 March 2020; Published: 1 April 2020

check for updates

\begin{abstract}
The properties of the segregated flow model (SFM), which considers split intestinal flow patterns perfusing an active enterocyte region that houses enzymes and transporters $(<20 \%$ of the total intestinal blood flow) and an inactive serosal region $(>80 \%)$, were compared to those of the traditional model (TM), wherein $100 \%$ of the flow perfuses the non-segregated intestine tissue. The appropriateness of the SFM model is important in terms of drug absorption and intestinal and liver drug metabolism. Model behaviors were examined with respect to intestinally (M1) versus hepatically (M2) formed metabolites and the availabilities in the intestine $\left(\mathrm{F}_{\mathrm{I}}\right)$ and liver $\left(\mathrm{F}_{\mathrm{H}}\right)$ and the route of drug administration. The \%contribution of the intestine to total first-pass metabolism bears a reciprocal relation to that for the liver, since the intestine, a gateway tissue, regulates the flow of substrate to the liver. The SFM predicts the highest and lowest M1 formed with oral (po) and intravenous (iv) dosing, respectively, whereas the extent of M1 formation is similar for the drug administered po or iv according to the TM, and these values sit intermediate those of the SFM. The SFM is significant, as this drug metabolism model explains route-dependent intestinal metabolism, describing a higher extent of intestinal metabolism with po versus the much reduced or absence of intestinal metabolism with iv dosing. A similar pattern exists for drug-drug interactions (DDIs). The inhibitor or inducer exerts its greatest effect on victim drugs when both inhibitor/inducer and drug are given po. With po dosing, more drug or inhibitor/inducer is brought into the intestine for DDIs. The bypass of flow and drug to the enterocyte region of the intestine after intravenous administration adds complications to in vitro-in vivo extrapolations (IVIVE).
\end{abstract}

Keywords: segregated flow intestinal model (SFM); traditional model (TM); route-dependent intestinal metabolism; first-pass effect; drug-drug interactions; $\mathrm{DDI}$; in vitro in vivo extrapolations; IVIVE

\section{The Intestine-Liver Unit}

The extent of the absorption of orally administered drugs is controlled by the intestine and liver, which are anatomically linked as a serial unit that is sequentially perfused by the circulation (Figure 1). The intestine is the gateway tissue to the liver and is important for drug absorption and first-pass removal. The superior mesenteric artery (SMA) supplies blood to the small intestine and its venous drainage, together with venous returns from the spleen, pancreas, gallbladder and gastrointestinal tract (GIT) including the stomach, constitute the hepatic portal vein flow $\left(\mathrm{Q}_{\mathrm{PV}}\right)$, which is approximately $75 \%$ of the total liver blood flow, $\mathrm{Q}_{\mathrm{H}}$. Together with the hepatic artery $\left(\mathrm{Q}_{\mathrm{HA}}\right)$, the remaining $25 \%$ of $\mathrm{Q}_{\mathrm{H}}$, the dual flows collectively perfuse the liver. 
The intestine is endowed with absorptive transmembrane transporters in simple columnar, epithelial cells known as enterocytes that line the inner surfaces of the small intestine. These cells contain numerous protrusions known as the villi and microvilli that increase the surface area multiple-fold to absorb drug molecules or nutrients from the gut lumen. Intestinal absorption models have been classically linked to drug properties and the dosage form ( $\mathrm{pKa}, \log \mathrm{P}$, and solubility), as well as the physiology of the gastrointestinal tract $(\mathrm{pH}$, gastrointestinal transit time, gastric emptying time, surface area, and microbiota) that control the fraction of dose absorbed $\left(\mathrm{F}_{\mathrm{a}}\right)$ [1-11]. In addition to passive diffusion, absorptive transporters known as the apical solute carrier transporters (SLC), as exemplified by the PEPT1 (oligopeptide transporter 1), OATP1A2, OATP2B1 (the organic anion transporting polypeptide 1A1 and 2B1), MCT1 (the monocarboxylic acid transporter 1), ASBT (apical sodium dependent bile acid transporter) that reclaims bile acids, and OCT (organic cation transporter), facilitate the entry of weak acids and weak bases [12-18]. Counterbalancing drug entry are the efflux transporters - the P-gp (P-glycoprotein), BCRP (breast cancer resistance protein) and MRP2 (multidrug resistance-associated protein 2) that mediate drug or metabolite secretion back to the intestinal lumen $[19,20]$, and this backward flux tends to reduce the net absorption of solutes. The OST $\alpha$ and OST $\beta$ (organic solute transporter $\alpha$ and $\beta$, half-transporters) transport bile acids out of the enterocytes [21]. It is well recognized that P-gp is capable of secreting highly lipophilic drugs [22,23]. Since lipophilic drugs with high solubility and permeability (Biopharmaceutical Classification System or BCS, Class I) are readily reabsorbed, the excretory function of P-gp is readily nullified [24]. The significance of P-gp, being more abundant distally in the ileum is, therefore, reduced for drugs that are readily reabsorbed $[20,23,25,26]$. However, for highly soluble but poorly permeable Class III BCS drugs, P-gp is more effective in reducing intestinal drug absorption [7]. It is also notable that drug permeability can be influenced by the $\mathrm{pH}$ of the intestinal lumen that becomes more and more basic and in turn, influence the extent of drug absorbed [3,8]. Segment-dependent decline in membrane permeability, reduced surface area from the duodenum to ileum [27] and pH changes along the intestine $[8,28]$ are noted. These variables will modulate the extent of passive drug absorption.

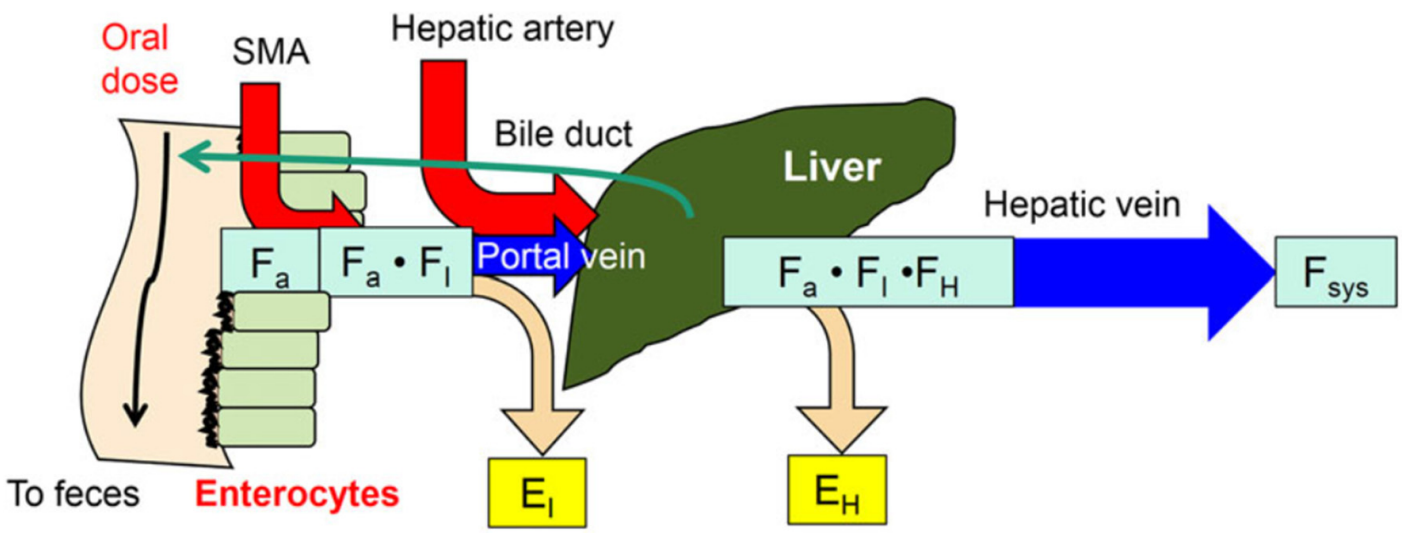

Figure 1. The intestine as a gateway tissue to the liver. Because of intestinal removal [extraction ratio, $E_{I}$ or $\left.\left(1-F_{I}\right)\right]$, the drug entering the liver is reduced, and the liver may further remove the drug with a liver extraction ratio $\left(E_{H}\right)$ to effect first-pass metabolism. The fraction absorbed, $F_{a}$ and $F_{I}$ or $(1-$ $\left.E_{I}\right)$, and $F_{H}$ or $\left(1-E_{H}\right)$ influence the systemic bioavailability, $F_{\text {sys. }}$ This figure was reproduced with permission from Noh and Pang [18], Wiley, 2019.

After crossing the intestinal membrane, the drug is met with metabolizing enzymes such as the cytochromes P450 3A (CYP3A) and UDP-glucuronosyltransferases, UGTs [29-32]. The most abundant CYP isoform is CYP3A4, which exceeds other isoforms such as 2C9, 2C19 > 2J2 > 2D6 that are present in lower quantities [31,33-35]. UGT 1A (1A1, 1A6, 1A5, 1A8, and 1A10) and 2B (2B7, 2B15, and 2B17) subfamilies are present to mediate the glucuronidation of morphine, raloxifene, mycophenolate, bisphenol A and gemfibrozil [36-40]. The intestinal metabolic activities for CYP3A4 and some of 
the UGTs are comparable to, or higher than, those in the liver [31,41,42]. Cytosolic glutathione S-transferases [43,44] are found abundantly, whereas epoxide hydrolases [43] and sulfotransferases (SULT) [45] are present at much lower quantities in the intestine.

The availability of the intestine $\left(\mathrm{F}_{\mathrm{I}}\right)$ after intestinal metabolism or secretion is defined as $\left(1-\mathrm{E}_{\mathrm{I}}\right)$ [where $\mathrm{E}_{\mathrm{I}}$ is the intestinal extraction ratio], and hepatic availability, $\mathrm{F}_{\mathrm{H}}$, is given by $\left(1-\mathrm{E}_{\mathrm{H}}\right)$ [where $\mathrm{E}_{\mathrm{H}}$ is the hepatic extraction ratio]. The overall systemic availability, $\mathrm{F}_{\text {sys }}$, is given by $\mathrm{F}_{\mathrm{a}} \mathrm{F}_{\mathrm{I}} \mathrm{F}_{\mathrm{H}}$. Following oral (po) drug dosing, the fraction of the dose absorbed $\left(\mathrm{F}_{\mathrm{a}}\right)$ is attributed to dosage forms and/or solubility properties, intestinal removal via metabolism or secretion (defined by the intestinal extraction ratio, $\mathrm{E}_{\mathrm{I}}$ ), and liver removal (defined as the hepatic extraction ratio, $\mathrm{E}_{\mathrm{H}}$ ), respectively. The product of the availabilities, $\mathrm{F}_{\mathrm{a}} \mathrm{F}_{\mathrm{I}} \mathrm{F}_{\mathrm{H}}$, constitute the net fraction, the systemic availability, $\mathrm{F}_{\text {sys }}$. For this reason, the intestine and liver are both capable of removing a significant proportion of the orally administered dose, a phenomenon known as the first-pass effect [46]. The extent of intestinal versus liver removal of drugs is therefore intimately related [47-50].

\section{Reason or Need for Intestinal Flow Models}

Although the development of clearance concepts for the intestine has lagged behind that for the liver [51-53], there have been some activities trending towards the fabrication of a useful and meaningful intestine clearance model to predict the extent of removal and examine how the intestine influences the rate of liver removal according to the route of drug administration. The correct intestinal model will exert serious implications in terms of drug-drug interactions (DDIs) with inducers or inhibitors, or in terms of in vitro-in vivo extrapolation (IVIVE).

\section{Route-Dependent Intestinal Metabolism}

Midazolam is a prototypic probe substrate of CYP3A4 metabolism that is often utilized for the screening of CYP3A4 and CYP3A5 activities in inhibition or induction studies [42,54-58]. Midazolam is metabolized by both the intestine and liver [42,59]. For the completely absorbed drug $\left(\mathrm{F}_{\mathrm{a}} \sim 1\right)$, there was a dramatically lower intestinal extraction ratio $\left(\mathrm{E}_{\mathrm{I}}=0.08\right)$, measured across the arterial and hepatic portal venous blood for midazolam after its intravenous administration among anhepatic patients whose livers were removed during transplantation surgery [59]. In comparison, the mean fraction metabolized across the intestinal mucosa when given intraduodenally was much higher $\left(E_{I}=0.43\right)$. This first, direct evidence uniquely shows route-dependent metabolism of the small intestine. Clinically, the erythromycin breath test relates well to the midazolam unbound liver clearance and not correlated to the intestinal clearance [60]. For radiolabeled (-)morphine that forms morphine 3-glucuronide (M3G) in both the intestine and liver, M3G was absent and undetectable in the vascularly perfused rat intestine preparation when morphine from the reservoir recirculated the rat intestine, a scenario akin to the systemic administration of morphine. This contrasts the copious presence of the radiolabeled M3G metabolite in both the intestinal lumen and reservoir after the intraduodenal administration of morphine into the gut lumen [61]. Additional animal and human studies attest to the same trend of a higher extent of intestinal metabolism after oral (po) than after intravenous (iv) drug administration (Table 1). These examples serve as direct evidence that display route-dependent metabolism of the small intestine. There will be a corresponding route-dependent change in the proportion of liver metabolites formed as well, since the unmetabolized drug leaving the intestine now enters the liver for further processing. 
Table 1. Examples of route-dependent intestinal metabolism.

\begin{tabular}{|c|c|c|c|c|}
\hline Compound & System & Enzyme/Metabolite & Examples & References \\
\hline Enalapril & $\begin{array}{l}\text { Perfused rat intestine-liver } \\
\text { preparation }\end{array}$ & Esterase/enalaprilat & $\begin{array}{l}\text { Enalaprilat formed from } \\
\text { enalapril after po } \\
\text { administration but not } \\
\text { systemic administration }\end{array}$ & [62] \\
\hline Acetaminophen & $\begin{array}{l}\text { Perfused rat small } \\
\text { intestine preparation }\end{array}$ & $\begin{array}{l}\text { Ugt1a6/acetaminophen } \\
\text { glucuronide }\end{array}$ & $\begin{array}{l}\text { Metabolite observed after } \\
\text { intraduodenal but not } \\
\text { systemic dosing }\end{array}$ & [63] \\
\hline $\begin{array}{l}(-)-6-a m i n o c a r b o v i r \\
(6 A C)\end{array}$ & $\begin{array}{l}\text { Perfused rat small } \\
\text { intestine preparation }\end{array}$ & $\begin{array}{l}\text { Adenosine deaminase activates } \\
\text { (-)-carbovir to } 6 \mathrm{AC}\end{array}$ & $\begin{array}{l}\text { 6AC was highly extracted } \\
\text { by intestine after luminal } \\
\text { dosing }(0.54) \text { compared to } \\
\text { reservoir dosing }(0.08)\end{array}$ & {$[64]$} \\
\hline Morphine & $\begin{array}{l}\text { Perfused rat small } \\
\text { intestine preparation }\end{array}$ & $\begin{array}{c}\text { Ugt2b1/ } \\
\text { morphine 3-glucuronide (M3G) }\end{array}$ & $\begin{array}{l}\text { M3G appeared after } \\
\text { intraduodenal but not } \\
\text { systemic dosing }\end{array}$ & [61] \\
\hline $\begin{array}{c}\mathrm{L}-754,394, \\
\text { (furanopyridine } \\
\text { derivative) }\end{array}$ & $\begin{array}{l}\text { Rats and dogs in vivo and } \\
\text { rat liver perfusion }\end{array}$ & $\begin{array}{c}\text { Cyp3a/ } \\
\text { epoxide intermediate }\end{array}$ & $\begin{array}{l}\text { Inhibition of L-754,394 and } \\
\text { its metabolites by Cyp3a is } \\
\text { much greater for po than } \\
\text { iv administration of drug }\end{array}$ & {$[65]$} \\
\hline Cyclosporine & Human in vivo & CYP3A4/AM1 and AM9 & $\begin{array}{l}\text { Metabolites: AM1 and } \\
\text { AM9 are lower after iv } \\
\text { compared to po }\end{array}$ & {$[66]$} \\
\hline Verapamil & Human in vivo & CYP3A4 and 3A5/ norverapamil & $\begin{array}{l}\text { Metabolite, norverapamil } \\
\text { formation after po > iv }\end{array}$ & [67] \\
\hline Hydralazine & Human in vivo & $\begin{array}{c}\text { Acetyltransferase/ } \\
\text { 3-methyl-striazolo-3,4, } \\
\alpha \text {-phthalazine (MTP) }\end{array}$ & $\begin{array}{c}\text { More MTP formation } \\
\text { observed after oral dosing } \\
\text { than iv dosing }\end{array}$ & {$[68]$} \\
\hline Cyclobenzaprine & Human in vivo & $\begin{array}{c}\text { UGT/ } \\
\text { cyclobenzaprine glucuronide } \\
\text { (CBG) }\end{array}$ & $\begin{array}{c}\text { Formation of CBG was } \\
\text { greater for the oral than for } \\
\text { parenteral case }\end{array}$ & [69] \\
\hline $\begin{array}{l}\text { Midazolam } \\
\quad(\mathrm{MDZ})\end{array}$ & Human in vivo & $\begin{array}{c}\text { CYP3A4/ } \\
\text { 1'-OH and 4-OH MDZ }\end{array}$ & $\begin{array}{c}\mathrm{E}_{\mathrm{I}} \text { after intraduodenal } \\
\text { administration }>>\mathrm{E}_{\mathrm{I}} \text { for iv } \\
\text { administration }\end{array}$ & {$[59,70]$} \\
\hline Methyldopa & Human in vivo & $\begin{array}{c}\text { SULT/ } \\
\text { methyldopa sulfate (MS) }\end{array}$ & $\begin{array}{l}\text { Greater formation of MS } \\
\text { after po than iv dosing of } \\
\text { M }\end{array}$ & [71] \\
\hline Quinidine & Human in vivo & $\begin{array}{l}\text { CYP3A/ } \\
\text { 3-hydroxyquinidine }\end{array}$ & $\begin{array}{l}\text { More 3-hydroxyquinidine } \\
\text { formed via oral compared } \\
\text { to iv route }\end{array}$ & {$[72]$} \\
\hline
\end{tabular}

\section{Intestinal Flow Models: Segregated Flow (SFM), $Q_{G u t}$ and Traditional (TM) Models}

Compartmental models are ill equipped to examine the extent of drug metabolism among metabolizing tissues or organs that are arranged serially. Hence, physiologically based pharmacokinetic (PBPK) modeling of the intestine and liver works a lot better. The approach has been used to appraise the extent of intestine vs. liver removal of drugs [48,49,73-78]. Here, the view is that the intestine is perfused $100 \%$ by superior mesenteric arterial flow (QSMA), which drains into the portal venous blood ( $\mathrm{QPV}_{\mathrm{PV}}$ ) for the traditional intestinal model (TM), and, upon combining with $\mathrm{Q}_{\mathrm{HA}}$, these flows in turn perfuse the liver. However, the TM would not explain route-dependent intestinal metabolism on midazolam [59] and morphine [61], which propelled us to develop useful intestinal flow models that can describe this phenomenon. The segregated flow model (SFM) describes a split flow pattern, as proposed by Klippert and Noordhoek [79], with a lower flow rate perfusing the active, enterocyte region ( $f_{Q}$ or fraction of the total intestinal flow, $<20 \%$ ) that houses the enzymes and absorptive/efflux transporters, and the remainder flow $(>80 \%)$ perfusing the non-active, serosal region has since surfaced [80]. With oral administration, the entire dose amount needs to cross into the enterocyte region - the volume of which is conveniently viewed as $\left(f_{Q^{\prime}} V_{\text {int }}\right)$, where $V_{\text {int }}\left(\right.$ or $\left.V_{I}\right)$ is the volume of the total intestine-whereas, for intravenous dosing, $<20 \%$ of the drug in the circulation reaches the enterocyte region, and this will effectively reduce the rate of drug removal by the intestine. The 
segregated flow behavior of the intestine is found to explain route-dependent intestinal removal observed for many drugs.

A similar flow model, the $Q_{G u t}$ model [81-83], was coined as a minimal model based on the well-stirred model equation for the liver, namely, $F_{I}=\frac{Q_{G u t}}{Q_{G u t}+f_{B} C L_{\text {int }}^{I}}$ [49], after the equation of Yang et al. [83] was corrected upon substitution of $f u_{B}$ for the unbound fraction to intestinal tissue, $f u_{I}$. Since the villous flow $\left(Q_{\text {villi }}\right)$ is $6 \%$ of the cardiac output as $19 \mathrm{~L} / \mathrm{h}$, the ratio of the $\mathrm{Q}_{\text {villi }} / \mathrm{Q}_{\mathrm{PV}}$ or $\mathrm{f}_{\mathrm{Q}}$ value for the $\mathrm{Q}_{\mathrm{Gut}}$ model is as high as 0.484 for a lipophilic drug such as midazolam [81-83]. Notably, $\mathrm{f}_{\mathrm{Q}}$ is different among these flow models: the SFM $\left(f_{Q}<0.2\right), Q_{G u t}$ model $\left(f_{Q}=0.484\right)$ and TM $\left(f_{Q}=1\right)$. The $f_{Q}$ value is expected to affect the extent of intestine and liver removal $\left(\mathrm{E}_{\mathrm{I}}\right.$ and $\left.\mathrm{E}_{\mathrm{H}}\right)$ in the intestine-liver unit with respect to the route of drug administration.

\section{Equations for Prediction of Route-Dependent Intestinal Removal}

There are major differences in drug distribution and therefore intestinal drug clearance when the drug is entering from gut lumen into the villous tip or from the circulation (drug given intravenously) (Figure 2). For the TM, whereby the total intestinal flow perfuses the entire intestine $\left(f_{Q}=1\right)$, there is no difference in the distribution and clearance of drug between oral and intravenous administration when the enterocyte and serosal regions are meshed together (Figure 2A). After po administration, the drug is absorbed into the enterocyte (yellow arrow) and is well distributed in the enterocyte (right graph); the distribution of drug into the enterocyte is also similar after intravenous administration, and the drug is again well-distributed into the enterocyte $\left(f_{Q}=1\right)$. For the SFM (Figure $2 B$ ), the extent of distribution after po dosing for a rapidly absorbed drug is similar to that as for TM. Since the enterocyte region is perfused with a lower flow rate $\left(f_{\mathrm{Q}^{\prime}} \mathrm{Q}_{\mathrm{PV}}\right)$ according to the $\mathrm{SFM}$, its drug extraction ratio for $\mathrm{E}_{\mathrm{I}, \mathrm{po}, \mathrm{SFM}}$ is therefore slightly higher than that for the $\mathrm{TM}, \mathrm{E}_{\mathrm{I}, \mathrm{po}, \mathrm{TM}}$, as the drug is associated with a longer transit time in the tissue [18]. However for iv dosing, there is a reduced distribution of drug reaching the enterocyte due to the reduced intestinal flow $\left(\mathrm{f}_{\mathrm{Q}}<0.2\right)$, and there will be a smaller intestinal clearance pursuant to intravenous dosing (Figure 2B). Thus $\mathrm{E}_{\mathrm{I}, \mathrm{po}, \mathrm{SFM}}>\mathrm{E}_{\mathrm{I}, \mathrm{iv}, \mathrm{SFM}}$ or $\mathrm{F}_{\mathrm{I}, \mathrm{iv}, \mathrm{SFM}}>$ $\mathrm{F}_{\mathrm{I} \text {,po,SFM }}$ (Figure 2B) when the drug is shunted away from the enterocyte region, especially for highly permeable drugs entering the intestinal tissue from the circulation than from the gut lumen [18,80].

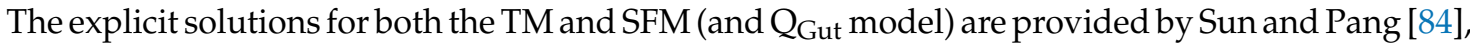
who placed the intestine and liver into simple or semi-physiologically based pharmacokinetic (PBPK) models upon viewing both metabolic as well as transport (basolateral influx and efflux) pathways in the intestine and liver (Figure 3). The only difference between the TM and SFM (or Q $\mathrm{Qut}_{\text {model) }}$ is the presence of an additional intestinal compartment, since the intestine is now denoted as two subcompartments, the enterocyte and serosa, for the SFM and $Q_{\text {Gut }}$ model. For simplistic assignment of the volume and flow, $\mathrm{f}_{\mathrm{Q}} \times$ volume or flow are used to designate the enterocyte volume and flow, respectively, and $\left(1-f_{Q}\right) \times$ volume or flow are used to denote the serosal volume and flow, respectively. A common solution ([Equation (1)] now surfaces to represent the systemic bioavailability with oral administration [84]. This common equation may be used to describe bioavailability, $F_{\text {sys, }}$ when $f_{Q}=1$, 0.484 and $<0.2$, respectively, for the TM, $Q_{\text {Gut }}$ model, and the SFM.

$$
\begin{aligned}
& \frac{\mathrm{AUC}_{\mathrm{po}} / \text { Dose }_{\mathrm{po}}}{\mathrm{AUC}_{\mathrm{jy}} / \text { Dose }_{\mathrm{iv}}}=\mathrm{F}_{\mathrm{sys}}=\mathrm{F}_{\mathrm{a}} \mathrm{F}_{\mathrm{I}} \mathrm{F}_{\mathrm{H}}
\end{aligned}
$$

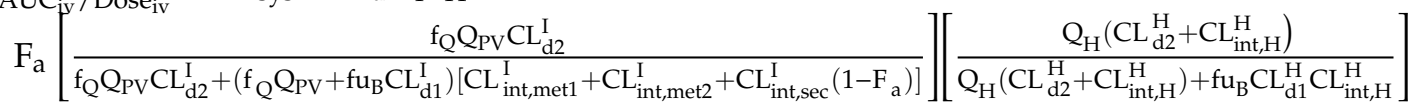

where $C L_{d 1}^{I}$ is the influx transport clearance and $C L_{d 2}^{I}$ is the efflux transport clearance. $C_{\text {int,met }}^{I}$ is the intestinal intrinsic metabolic clearance (for pathways 1 or 2) and $C L_{\text {int,sec }}^{I}$ is the secretory intestinal intrinsic clearance. In the liver, the sum of $\mathrm{CL}_{\text {int,sec }}^{\mathrm{H}}$ and $\mathrm{CL}_{\text {int,met }}^{\mathrm{H}}$ is $\mathrm{CL}_{\text {int }}^{\mathrm{H}}$; fu $\mathrm{fu}_{\mathrm{B}}$ is the unbound fraction in blood, and $\mathrm{Q}_{\mathrm{PV}}$ and $\mathrm{Q}_{\mathrm{H}}$ are the portal venous flow and total liver blood flow, respectively. The superscripts I and $\mathrm{H}$ denote the intestine and liver, respectively. Notably, the unbound fractions of drug in intestine and liver tissue $\left(\mathrm{fu}_{\mathrm{I}}\right.$ and $\left.f \mathrm{u}_{\mathrm{H}}\right)$ are canceled out in the manipulation. 
(A)

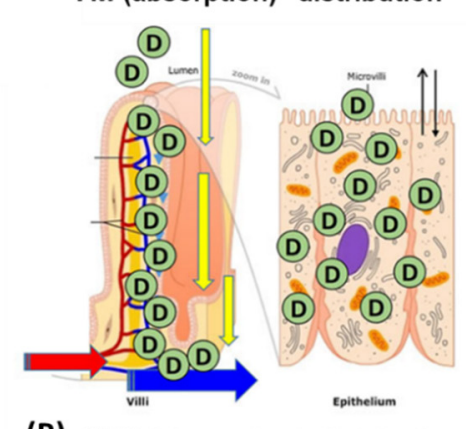

(B) SFM (absorption) distribution

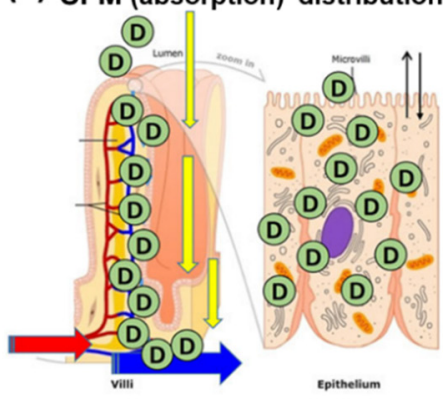

TM (intravenous) distribution
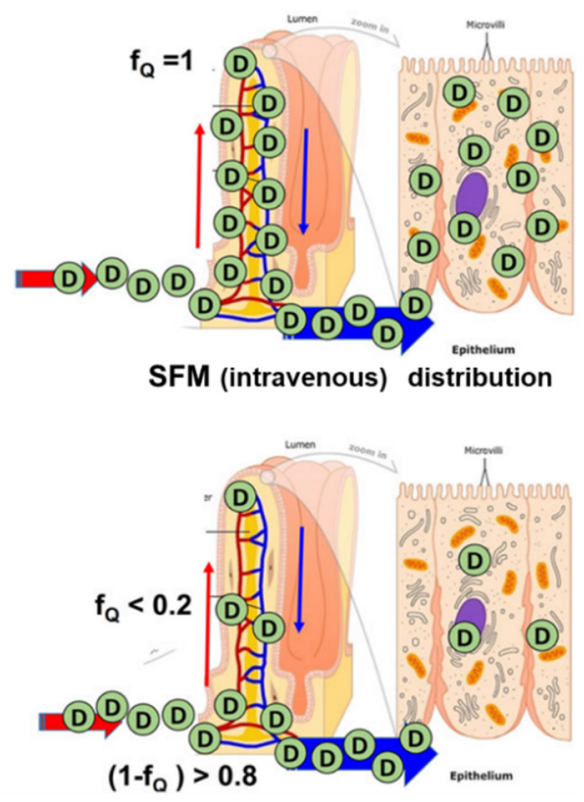

Figure 2. Schematic of drug molecules (D) traversing the intestinal membrane and entering the enterocyte for the tradtional model (TM) (A) and segregated flow model (SFM) (B). After po admininstration, the drug is absorbed into the enterocyte (yellow arrow) and distributed abundantly in the epithelisum (adjacent) for both the TM and SFM. After intravenous administration, the drug is distributed to the same extent in the epithelium according to the TM $\left(f_{Q}=1\right)$ while the $\operatorname{SFM}\left(f_{Q}<0.2\right)$ predicts a much lower distribution of drug in enterocytes. This figure was reproduced with permission from Noh and Pang [18], Wiley, 2019.

\section{TM-PBPK}

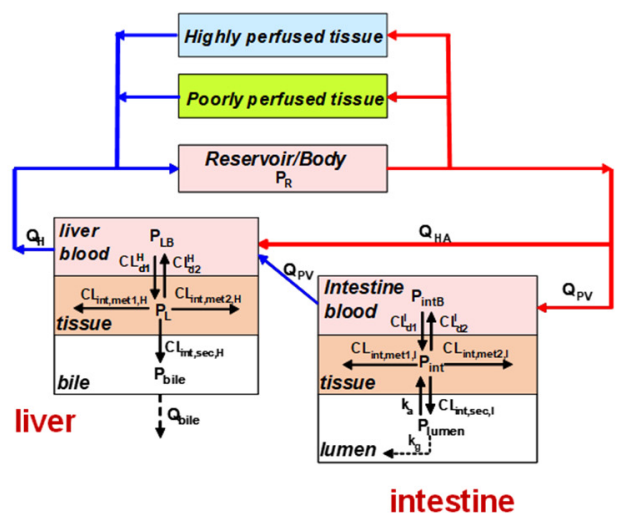

\section{SFM-PBPK}

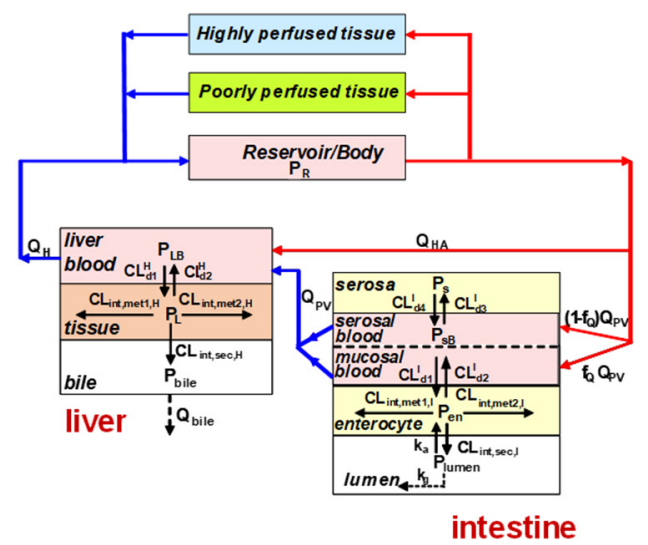

Figure 3. Physiologically based pharmacokinetic (PBPK) models depicting the intestine as a single tissue or compartment for the TM (left) or as the two subcompartments, the enterocyte and serosal subcompartments for the SFM (right), perfused by segregated flows. This figure was reproduced with permission from Sun and Pang [84], Springer, 2010.

For a drug in the circulation entering the intestine, the rate of drug removal by the enterocyte is $f_{Q}$. $Q_{P V}\left(1-F_{I}\right) \cdot C_{A}$, but there is no removal by the serosal region (Figure 4$)$. The split flow pattern for the SFM or $Q_{\text {Gut }}$ model results in a flow-averaged outflow, portal venous concentration, $\overline{\mathrm{C}}_{\mathrm{PV}}$ [49].

$$
\overline{\mathrm{C}}_{\mathrm{PV}}=\frac{\mathrm{f}_{\mathrm{Q}} \mathrm{Q}_{\mathrm{PV}} \mathrm{F}_{\mathrm{I}} \mathrm{C}_{\mathrm{A}}+\left(1-\mathrm{f}_{\mathrm{Q}}\right) \mathrm{Q}_{\mathrm{PV}} \mathrm{C}_{\mathrm{A}}}{\mathrm{Q}_{\mathrm{PV}}}=\mathrm{C}_{\mathrm{A}}\left[\mathrm{f}_{\mathrm{Q}} \mathrm{F}_{\mathrm{I}}+\left(1-\mathrm{f}_{\mathrm{Q}}\right)\right]
$$



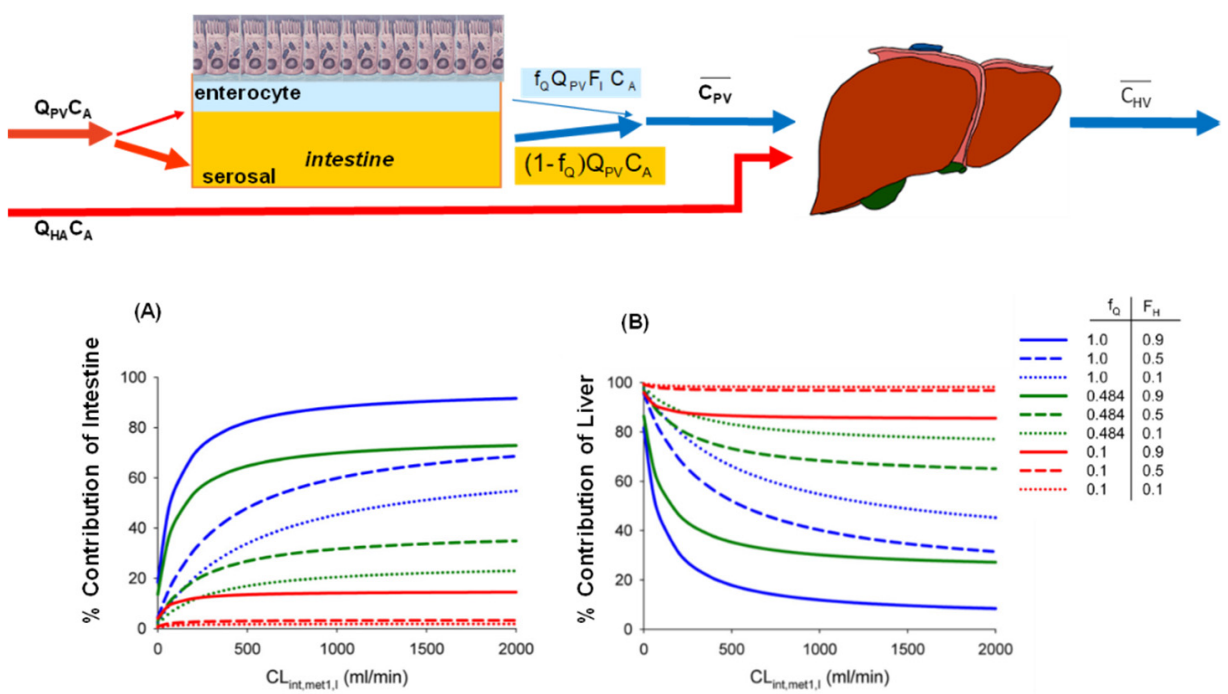

Figure 4. Drug removal by the intestine-liver unit: the intestine controls the substrate flux to the liver. The contributions of intestinal (A) and liver (B) removal are given by Equations (3) and (4). The drug in the circulation enters two subcompartments of the intestine-the enterocyte and serosal compartments. Removal by the enterocyte but not seroal compartment results in a flow-averaged portal venous concentration, $\overline{\mathrm{C}}_{\mathrm{PV}}$. If intestinal removal is high, the contribution by the liver is opposite and will be low. This figure was modified with permission from Pang and Chow [49], ASPET, 2012.

This flow-averaged portal venous concentration is then combined with the arterial concentration $\left(C_{A}\right)$ to perfuse the liver. Along the same line of reasoning, the rates of removal of drug by the intestine and liver or the fractional contributions are given by,

$$
\frac{v_{I}}{v_{I}+v_{H}}=\frac{f_{Q} Q_{P V}\left(1-F_{I}\right)}{f_{Q} Q_{P V}\left(1-F_{I}\right)+E_{H}\left\langle Q_{P V}\left[f_{Q} F_{I}+\left(1-f_{Q}\right)\right]+Q_{H A}\right\rangle}
$$

and

$$
\frac{\mathrm{v}_{\mathrm{H}}}{\mathrm{v}_{\mathrm{I}}+\mathrm{v}_{\mathrm{H}}}=\frac{\mathrm{E}_{\mathrm{H}}\left\langle\mathrm{Q}_{\mathrm{PV}}\left[\mathrm{f}_{\mathrm{Q}} \mathrm{F}_{\mathrm{I}}+\left(1-\mathrm{f}_{\mathrm{Q}}\right)\right]+\mathrm{Q}_{\mathrm{HA}}\right\rangle}{\mathrm{f}_{\mathrm{Q}} \mathrm{Q}_{\mathrm{PV}}\left(1-\mathrm{F}_{\mathrm{I}}\right)+\mathrm{E}_{\mathrm{H}}\left\langle\mathrm{Q}_{\mathrm{PV}}\left[\mathrm{f}_{\mathrm{Q}} \mathrm{F}_{\mathrm{I}}+\left(1-\mathrm{f}_{\mathrm{Q}}\right)\right]+\mathrm{Q}_{\mathrm{HA}}\right\rangle}
$$

The contributions of the intestine $\left(\mathrm{v}_{\mathrm{I}}\right)$ and liver $\left(\mathrm{v}_{\mathrm{H}}\right)$ in first-pass removal are hence described by Equations (3) and (4). With $\mathrm{f}_{\mathrm{Q}}$ values $=1$ (left) $(\mathrm{TM}),=0.1(\mathrm{SFM})$, or $=0.484$ ( $\mathrm{Q}_{\text {Gut }}$ model) and with the assumption that $\mathrm{Q}_{\mathrm{PV}}$ is approximated by $\mathrm{Q}_{\mathrm{SMA}}$, simulations show that, for a drug entering the intestine from the circulation, the TM predicts the highest intestinal contribution by the intestine-liver unit, whereas the SFM predicts the least; the $Q_{\text {Gut }}$ model predicts values somewhere in the middle (Figure 4A). The importance of the intestine increases when the liver possesses a low enzymatic removal capacity (high $\mathrm{F}_{\mathrm{H}}$ ). Under the same scenario, results for the \%contribution by the liver are the exact opposites, since there is a reciprocal relation to the intestine (Figure 4B). For the SFM, which suggests a lower contribution of metabolism by the intestine for drugs entering from the circulation, the contribution by the liver to first-pass removal is higher than those predicted for the TM and $Q_{G u t}$ model, since there is a greater substrate flux entering the liver that will result in a greater \%contribution by the liver, especially for high $\mathrm{E}_{\mathrm{H}}$ drugs.

\section{Is the SFM the Better Intestinal Flow Model Compared to the TM?}

Theoretical development of the SFM readily explains the observed higher $\mathrm{E}_{\mathrm{I}}$ for midazolam and morphine given orally versus intravenously (also Table 1), as do many other drug examples or substrates. When different sets of in vivo or intestinal perfusion data were fitted to the TM versus the 
SFM, fits to the SFM were all superior over those for the TM. The fitted values of $f_{Q}$ were all $<0.2$, and the SFM was shown to better the TM statistically among all examples (Table 2). The villous flow pattern to the enterocyte region [85], being a low fraction $(<0.2)$, has also been suggested by Granger et al. [86]. A better discrimination between the TM and SFM occurs when metabolite data are present, as provided by the example of morphine, which forms morphine-3-glucuronide (M3G) by the intestine and liver in the rat in vivo. The discriminatory power for the morphine study was further provided by the biliary versus urinary excretion ratio of the metabolite, M3G, which is unable to cross the liver membrane due to its polarity [87]. The M3G presence in bile suggests that the origin of the metabolite is from the liver. The urinary morphine 3-glucuronide originates from both intestinal and liver metabolism, and the observed ratio of M3G in urine/bile associated with intraduodenal morphine dosing was 2.55-fold that with intravenous morphine administration, as predicted for the SFM [76]. The observations for morphine and morphine 3-glucuronide correlated much better with the predictions from the SFM than from TM.

Table 2. Fitted values of $\mathrm{f}_{\mathrm{Q}}$ in rodents in vivo and in perfusion preparations.

\begin{tabular}{cccc}
\hline Drug & $\begin{array}{c}\text { Fraction of Intestinal } \\
\text { Flow to Enterocytes }\left(\mathbf{f}_{\mathbf{Q}}\right)\end{array}$ & Experimental Condition & References \\
\hline Benzoic acid & 0.07 & Rat liver perfusion & {$[88]$} \\
\hline Codeine & 0.16 & Rat in vivo & {$[77]$} \\
\hline Digoxin & 0.20 & Rat intestinal perfusion & {$[26]$} \\
\hline Digoxin & 0.16 & Mouse in vivo & {$[89]$} \\
\hline Morphine & 0.10 & Rat in vivo & {$[76]$} \\
\hline Morphine & 0.024 & Rat intestinal perfusion & {$[80]$} \\
\hline 1,25-Dihydroxyvitamin $\mathrm{D}_{3}$ & 0.11 & Mouse in vivo & {$[87]$} \\
\hline
\end{tabular}

By contrast, there is practically no difference in the fitted results between the SFM and TM for codeine, the inactive precursor that is $\mathrm{N}$-demethylated to form morphine [77]. At first glance, the similarity of both the SFM and TM fits is unique, suggesting that the drug is not subject to intestinal metabolism. For codeine, rat Cyp2d1 (human CYP2D6) is of very low abundance in the intestine, and intestinal metabolism of codeine is very low. For that reason, the agreement of the TM and SFM fits to the codeine data infer a lack of intestine metabolism for codeine. We also recently observed the same pattern for the pan-inhibitor, ketoconazole, after oral and intravenous administration to the rat (unpublished information, Keumhan Noh, Lilly $\mathrm{Xu}$, and K. Sandy Pang).

\subsection{Implications on Formation of Intestinal and Liver Metabolites}

Noh and Pang [18] examined the formation of the metabolites: M1 from intestine and M2 from liver, as well as extraction ratios of the intestine with the route of drug administration. For TM, the simulations verified that $\mathrm{F}_{\mathrm{I}, \mathrm{po}, \mathrm{TM}}=\mathrm{F}_{\mathrm{I} \text {,iv,TM }}$ for highly permeable drugs, but $\mathrm{F}_{\mathrm{I}, \mathrm{po}, \mathrm{SFM}}<\mathrm{F}_{\mathrm{I}, \mathrm{iv}, \mathrm{SFM}}$ for SFM and $\mathrm{F}_{\mathrm{I}, \mathrm{po}, \mathrm{SFM}}<\mathrm{F}_{\mathrm{I} \text {,po,TM }}=\mathrm{F}_{\mathrm{I}, \mathrm{iv}, \mathrm{TM}}<\mathrm{F}_{\mathrm{I}, \mathrm{iv}, \mathrm{SFM}}$. The SFM predicts the highest formation of the M1 metabolite with oral dosing but the lowest formation of M1 with intravenous administration; the converse should occur for M2 formation from liver. From M1/M2, the ratio would further unveil that there is more $\mathrm{M} 2$ formation arising via the iv route because of direct delivery of drug via the hepatic artery to the liver. Additionally, M1 is less formed according to the SFM for drugs administered iv than po. For this reason, the ratio M1/M2 would always be smaller after intravenous administration according to the SFM as well as TM (Figure 5). 


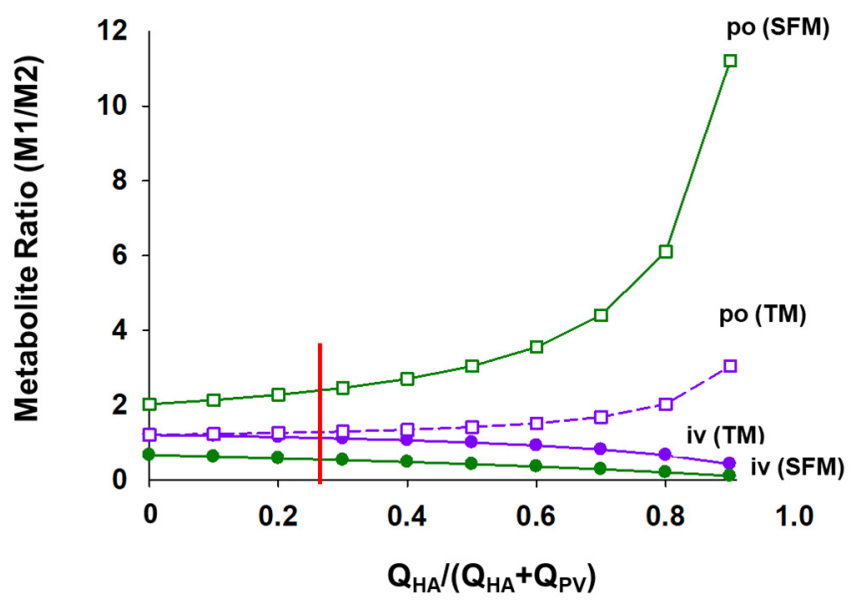

Figure 5. Formation of M1 and M2, specific metabolites formed by the intestine and liver, respecitvely, as simulated by Noh and Pang [18]. The hepatic arterial flow $\left(\mathrm{Q}_{\mathrm{HA}}\right)$, normally $25 \%$ of total liver blood flow (shown where red line is), delivers the drug directly into the liver, and this contributes M2 formation. Additionally, M2 formation is highest according to the SFM for iv drug administration wherein $\mathrm{M} 1$ formation is low due to the low $\mathrm{f}_{\mathrm{Q}}$. For the TM, the extent of $\mathrm{M} 2$ formation is identical for a drug given orally and intravenously, when there is no $\mathrm{Q}_{\mathrm{HA}}$ flow; the extent increases with increasing $\mathrm{Q}_{\mathrm{HA}}$. This figure was reproduced with permission from Noh and Pang [18], Wiley, 2019.

\subsection{Implications of the SFM on Drug-Drug Interactions (DDIs)}

Another reason for properly selecting the intestine flow model is on the prediction of DDI with an inducer or inhibitor. Because $>80 \%$ intestinal flow bypasses the enterocytes according to the SFM, the route of administration of the inhibitor/inducer, if oral, should be much more effective than the intravenous route, with the underlying reason that the inhibitor/inducer concentrations would be higher in the enterocyte region. Hence, the extent of DDIs is dependent on how the victim drug or inhibitor/inducer is administered and which intestinal flow model, TM or SFM, prevails (Table 3). For midazolam given intravenously $\left(2 \mathrm{mg}\right.$ ) or orally $(6 \mathrm{mg})$ to humans, its $\mathrm{AUC}_{\mathrm{iv}}$ increased 5 -fold, whereas $\mathrm{AUC}_{\text {po }}$ increased 16-fold upon pretreatment with 3 po doses of $200 \mathrm{mg}$ ketoconazole orally at $12 \mathrm{~h}$ prior to midazolam dosing, and twice at every $12 \mathrm{~h}$ thereafter [57]. For digoxin $(1 \mathrm{mg})$, the inducer rifampin ( $600 \mathrm{mg}$ daily po for 15 days) produced a dramatic lowering of $\mathrm{AUC}_{\mathrm{po}}$ but not $\mathrm{AUC}_{\mathrm{iv}}$ of digoxin due to a 3.5-fold induction of intestinal P-gp protein [20]. In monkeys, ketoconazole inhibited the metabolism of simvastatin, a typical Cyp3a substrate, when given orally and increased the $\mathrm{AUC}_{\mathrm{po}} 5$ to $10 \mathrm{x}$, without changing $\mathrm{AUC}_{\mathrm{iv}}$ for simvastatin given intravenously [90]. For midazolam, oral treatment $(50 \mathrm{mg} / \mathrm{kg} / \mathrm{day}$ for 4 days) of dexamethasone increased the $V_{\max }$ values for 1'-hydroxylation and 4-hydroxylation of midazolam in rat intestinal microsomes much more than that with iv dexamethasone [91]. For digoxin given to Wistar rats, purple grape juice (inhibitor of transporter or enzymes) increased the $\mathrm{AUC}_{\mathrm{po}}$ $(73 \%)$ but not $\mathrm{AUC}_{\mathrm{iv}}$ for digoxin [92]. There exist many other examples attesting to this interesting DDI pattern for orally but not intravenously administered victim drugs in the presence of inhibitors or inducers, also given orally (Table 3). These examples confirm the observation that inhibitors or inducers of intestinal enzymes act best after oral administration, since the concentration attained will be highest within the intestine, and the same goes for the victim drug. The inhibition expected for the SFM should be the greatest, and hence this would also create opposite changes in liver metabolism, since inhibition of the intestine leads to a greater flux of substrate towards liver metabolism. 
Table 3. Greater inhibitory or inductive effects after oral administration than iv administration for drug-drug interactions (DDIs) of the intestine.

\begin{tabular}{|c|c|c|c|c|}
\hline Compound & $\begin{array}{c}\text { Inducer/Inhibitor (Dosing } \\
\text { Route) }\end{array}$ & $\begin{array}{c}\text { Enzyme } \\
\text { /Transporter }\end{array}$ & Outcome & Reference \\
\hline \multicolumn{5}{|c|}{ Induction Studies } \\
\hline Alfentanil & Rifampicin (po) & CYP & $\begin{array}{c}\text { Decrease in } \\
\text { AUC }_{\text {po }} / \mathrm{AUC}_{\mathrm{iv}}=8.2\end{array}$ & [93] \\
\hline Cyclosporin & Rifampicin (po) & CYP & $\begin{array}{c}\text { Decrease in } \\
\text { AUC }_{\mathrm{po}} / \mathrm{AUC}_{\mathrm{iv}}=2.6\end{array}$ & [94] \\
\hline Digoxin & Rifampicin (po) & P-gp & $\begin{array}{c}\text { Decrease in } \\
\mathrm{AUC}_{\mathrm{po}} / \mathrm{AUC}_{\mathrm{iv}}=1.3\end{array}$ & [20] \\
\hline Indinavir & Dexamethasone (po) & $\begin{array}{l}\text { CYP and } \\
\text { P-gp }\end{array}$ & $\begin{array}{c}\text { Decrease in } \\
\mathrm{AUC}_{\mathrm{po}} / \mathrm{AUC}_{\mathrm{iv}}=2.3\end{array}$ & [24] \\
\hline Methadone & Rifampicin (po) & CYP & 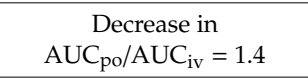 & [95] \\
\hline Midazolam & Rifampicin (po) & CYP & $\begin{array}{c}\text { Decrease in } \\
\text { AUC }_{\text {po }} / \mathrm{AUC}_{\mathrm{iv}}=4.4\end{array}$ & [96] \\
\hline Nifedipine & Rifampicin (po) & CYP & $\begin{array}{c}\text { Decrease in } \\
\text { AUC }_{\mathrm{po}} / \mathrm{AUC}_{\mathrm{iv}}=8.5\end{array}$ & [97] \\
\hline Talinolol & Rifampicin (po) & P-gp & $\begin{array}{c}\text { Decrease in } \\
\mathrm{AUC}_{\mathrm{po}} / \mathrm{AUC}_{\mathrm{iv}}=1.7\end{array}$ & [98] \\
\hline Tacrolimus & Rifampicin (po) & CYP & $\begin{array}{c}\text { Decrease in } \\
\mathrm{AUC}_{\mathrm{po}} / \mathrm{AUC}_{\mathrm{iv}}=2.0\end{array}$ & [99] \\
\hline Temsirolimus & Rifampicin (po) & CYP & $\begin{array}{c}\text { Decrease in } \\
\mathrm{AUC}_{\mathrm{po}} / \mathrm{AUC}_{\mathrm{iv}}=1.3\end{array}$ & [100] \\
\hline \multicolumn{5}{|c|}{ Inhibition Studies } \\
\hline Alfentanil & $\begin{array}{l}\text { Grapefruit juice (po) } \\
\text { Troleandomycin (po) }\end{array}$ & CYP & $\begin{array}{c}\text { Increase in } \\
\mathrm{AUC}_{\mathrm{po}} / \mathrm{AUC}_{\mathrm{iv}}=1.5-2.6\end{array}$ & [93] \\
\hline Atorvastatin & Itraconazole (iv) & $\begin{array}{l}\text { CYP and } \\
\text { P-gp }\end{array}$ & $\begin{array}{c}\mathrm{AUC}_{\mathrm{iv}+\mathrm{INH}} \\
/ \mathrm{AUC}_{\mathrm{iv}, \text { control }}=1.3 \\
\mathrm{AUC}_{\mathrm{po}+\mathrm{INH}} \\
/ \mathrm{AUC}_{\text {po control }}=2.2\end{array}$ & [101] \\
\hline Cyclosporine & $\begin{array}{c}\text { Carvedilol (po) } \\
\text { Grapefruit juice (po) Ketoconazole } \\
\text { (po) }\end{array}$ & CYP & $\begin{array}{c}\text { Increase of } \\
\mathrm{AUC}_{\mathrm{po}} / \mathrm{AUC}_{\mathrm{iv}}=1.5-2.8\end{array}$ & {$[66,102,103]$} \\
\hline Felodipine & Grapefruit juice (po) & CYP & $\begin{array}{c}\text { Increase of } \\
\mathrm{AUC}_{\mathrm{po}} / \mathrm{AUC}_{\mathrm{iv}}=1.9\end{array}$ & [104] \\
\hline Losartan & Ticlopidine (po) & CYP & $\begin{array}{c}\text { Increase of } \\
\mathrm{AUC}_{\mathrm{po}} / \mathrm{AUC}_{\mathrm{iv}}=1.2\end{array}$ & [105] \\
\hline Midazolam & $\begin{array}{c}\text { Clarithromycin (po) Diltiazem } \\
\text { (po) Erythromycin (po) } \\
\text { Fluconazole (po) Grapefruit juice } \\
\text { (po) Itraconazole (po) } \\
\text { Ketoconazole (po) Saquinavir (po) } \\
\text { Voriconazole (po) }\end{array}$ & CYP & $\begin{array}{c}\text { Increase of } \\
\mathrm{AUC}_{\mathrm{PO}} / \mathrm{AUC}_{\mathrm{IV}}=1.4-3.2\end{array}$ & {$[57,91,93,106-111]$} \\
\hline Nifedipine & $\begin{array}{c}\text { Grapefruit juice (po) licochalcone } \\
\text { A (po) }\end{array}$ & CYP & $\begin{array}{c}\text { Increase in } \\
\mathrm{AUC}_{\mathrm{po}} / \mathrm{AUC}_{\mathrm{iv}}=1.2-1.4\end{array}$ & {$[112,113]$} \\
\hline Saquanvir & Grapefruit juice (po) & CYP & $\begin{array}{c}\text { Increase in } \\
\mathrm{AUC}_{\mathrm{po}} / \mathrm{AUC}_{\mathrm{iv}}=1.7\end{array}$ & [114] \\
\hline Simvastatin & Ketoconazole (po) & CYP & $\begin{array}{c}\text { Increase in } \\
\mathrm{AUC}_{\mathrm{po}} / \mathrm{AUC}_{\mathrm{iv}}=5.0\end{array}$ & [90] \\
\hline Tacrolimus & Ketoconazole (po) & CYP & $\begin{array}{c}\text { Increase in } \\
\mathrm{AUC}_{\mathrm{po}} / \mathrm{AUC}_{\mathrm{iv}}=1.4\end{array}$ & [115] \\
\hline
\end{tabular}

Noh and Pang [18] recently explored the properties of the SFM and TM models with respect to inhibitors via simulations. Within the assigned, limited parameter space set forth for the drug example, the reduction in M1 formation is highest when both inhibitor (intestine inhibition constant, $\mathrm{K}_{\mathrm{i}}=2 \mu \mathrm{M}$ ) and drug are both given orally, and least or almost unaltered at all when the drug is given intravenously (Figure 6A). Inhibition of metabolism is revealed by the higher drug AUC in the presence of the inhibitor. Often, changes in metabolite patterns are able to reveal inhibition of enzymes within the tissue. For TM, the same extent of M1 formation occurs for both intravenous and oral drug 
administration, and inhibition of M1 formation is the same after iv or po drug administration. For SFM, a greater extent of inhibition exists for the drug given orally and least when given intravenously. Liver metabolism is in turn affected upon inhibition of the intestinal metabolism, and an inverse relation to that for the intestine is found.

(A)

Drug + inhibitor for intestine
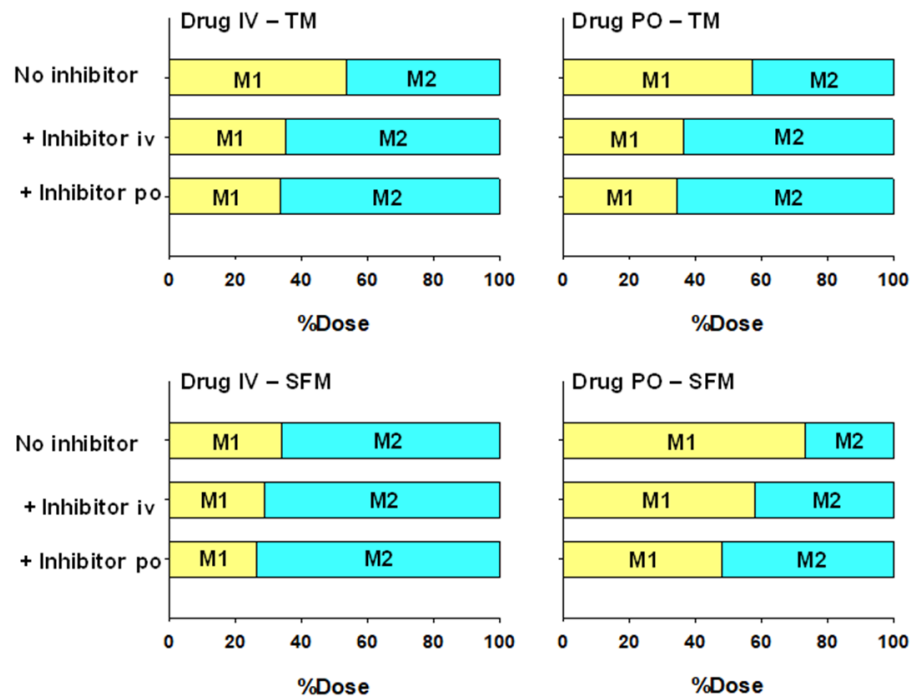

(B)

Drug + inhibitor for intestine \& liver
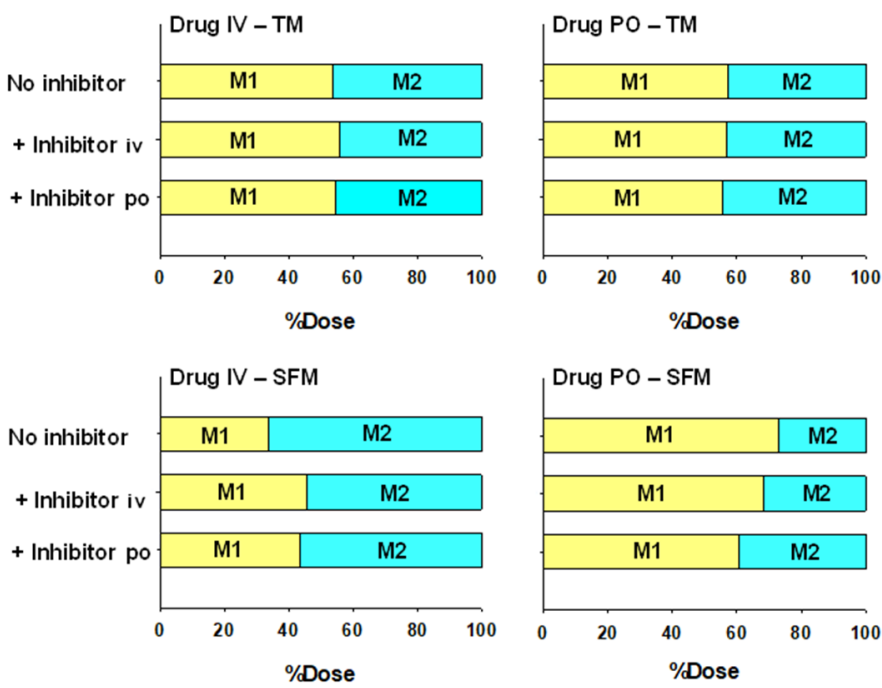

Figure 6. Simulation of intestinally (M1) and hepatically (M2) formed metabolites. For simulation, M1 and M2 were assumed to be inhibited within the intestine only (A), and both the intestine and liver (B) for a drug example ([18]; data in Table 6 of the reference). The simulation showed that the SFM predicted the highest and lowest M1 formation after oral and intravenous drug admintration, respectively, and the TM predicts a similar extent. The inhibition on intestinal metabolism is the greatest when both the inhibitor and drug are given orally, as predicted by the SFM (A). When both intestine and liver metabolism is inhibited, the pattern of change is not readily predictable (B). A greater liver inhibition exists after iv drug administration, and the extent of inhibition within the liver can exceed that in the intestine (B). This figure was reproduced with permission from data in Table 6 of Noh and Pang [18], Wiley, 2019.

The patterns of intestinal and liver metabolites formed upon inhibition of both the intestine and liver are less revealing as to which tissue is being inhibited, since the proportions of M1 to M2 formed 
do not always change in the same direction. When inhibition occurring for both the intestine and liver (same $\mathrm{K}_{\mathrm{i}}=2 \mu \mathrm{M}$ for M1 and M2 formation), the fluctuations for M1 and M2 are small for the TM and SFM for oral drug administration when inhibition of the intestine is highest. Although inhibition is noted for the victim drug, the extent of M1 formation may even increase due to inhibition of liver metabolism to a greater extent for the drug given intravenously due to the higher input with $\mathrm{Q}_{\mathrm{HA}}$, with inhibition of the liver being more severe than for the intestine (Figure 6B). It is surmised that the extent of change here depends very much on the parameter space and susceptibility of the intestine versus the liver to the inhibitor and route of administration. But a higher AUC of the drug is strong evidence for the presence of the inhibitor on intestinal and liver metabolism.

\subsection{Changes in Intestinal and Liver Metabolism with Respect to Flow to Intestine and Liver}

Different flow rates to the enterocyte region in the intestine-liver unit would affect intestinal and liver drug processing differentially. An increase in $\mathrm{Q}_{\mathrm{PV}}$ decreases the $\mathrm{E}_{\mathrm{I}, \mathrm{po}}$ (increased $\mathrm{F}_{\mathrm{I}, \mathrm{po}}$ ), allowing for more substrate flow to the liver for both the TM and SFM. With the greater substrate flux but faster transit in the liver, the rate of liver metabolism may remain the same although the increase in liver blood flow increases the $\mathrm{CL}_{\mathrm{H}}[47,50]$. The converse is also true, with a lower $\mathrm{Q}_{\mathrm{PV}}$ or $\mathrm{Q}_{\mathrm{SMA}}$, an increase in $\mathrm{E}_{\mathrm{I}}$ and a lower flux to the liver will result.

\subsection{Implications of the SFM on IVIVE}

The IVIVE of transporter function is difficult to deduce when different transit times in GIT, gastric emptying rates, varying $\mathrm{pH}$, and microenvironment exist [116]. The permeability, apical absorptive transporters, and split flow pattern of the intestine to the enterocyte and serosal regions, and efflux transporters complicate the IVIVE picture in the prediction of $\mathrm{F}_{\mathrm{a}}$ and $\mathrm{F}_{\mathrm{I}}$. In terms of IVIVE, Kadono et al. [117] employed permeability measurements in artificial membranes to obtain $F_{a}$ from the apparent permeability $\left(\mathrm{P}_{\mathrm{app}}\right.$ ) with the parallel artificial membrane permeability assay (PAMPA) and obtain $\mathrm{F}_{\mathrm{a}}$ and $F_{I}$ from a scaling factor against a standard such as midazolam using the Yang equation [83]. In addition, IVIVE may be poor for the SFM due to the split flow behavior of the intestinal models, when there is incomplete accessibility of the substrate in circulation to reach enterocytes to fully recruit the intestinal metabolic activity, and this translates to poor IVIVE for the liver. Moreover, methods for identification of intestinal enzymatic activities vary. There are differences in the intestinal functional activity with the mucosal scraping and buffer isolation methods $[70,118]$. Paine et al. [70] found CYP3A content in each intestinal segment as 30.6, 22.6 and $16.6 \mathrm{pmol} / \mathrm{mg}$ mucosal microsomal protein, with similar $\mathrm{K}_{\mathrm{m}}$ towards midazolam but varying $\mathrm{V}_{\max }$ values. von Richter et al. [119] showed that the CYP3A4 in isolated enterocytes ( $76 \mathrm{pmol} / \mathrm{mg}$ homogenate protein corresponded to $210 \mathrm{pmol} / \mathrm{mg}$ microsomal protein) and was 3.2-fold higher than that in corresponding liver samples, whereas the P-gp content was 7.2-fold higher in enterocyte homogenate than in liver. The CYP3A4 content from the isolated cell method is higher than that from mucosal scraping. Moreover, intestinal metabolism may occur within cells that are shed into the gut lumen that possess copious metabolic activities in the lumen [118]. Nishimuta et al. [120] employed human intestinal and human microsomes to predict the CYP3A intrinsic metabolic clearance for human intestinal microsomes (HIM) versus human liver microsomes (HLM) ( $\mathrm{CL}_{\text {int,HIM }}$ and $\mathrm{CL}_{\text {int,HLM}}$, corrected by the ratio of $\mathrm{CL}_{\text {int,HIM }}$ to $\mathrm{CL}_{\text {int,HLM }}$ ), and alamethicin-activated HIM for the clearance of UGT substrates. The CYP3A intestinal intrinsic clearance $\left(\mathrm{CL}_{\text {int,I,CYP3A }}\right)$ was highly correlated to hepatic intrinsic clearance $\left(\mathrm{CL}_{\text {int, } \mathrm{L}, \mathrm{CYP} 3 \mathrm{~A}}\right)$, being 2.2-fold higher in liver, although the correlation was poorer for UGTs. Ito and Houston [34] scaled up the $\mathrm{CL}_{\mathrm{int}, \mathrm{H}}$ with an empirical scaling factor (SF) of $6.2 \mathrm{~g}$ protein $/ \mathrm{kg}$ weight to compensate for the extent of underprediction for IVIVE in rats. Allometric scaling shows that in vitro microsomal data consistently underestimate $\mathrm{CL}_{\text {int,met, } \mathrm{I}}$ and $\mathrm{CL}_{\text {int,met, } \mathrm{H}}$. Hence, scaling and IVIVE remain somewhat empirical approaches. 


\section{Other Intestinal Models}

Our laboratory has extended the SFM to the segmental, segregated flow model (SSFM) to accommodate transporter and enzyme heterogeneity [121]. However, we have oversimplified the segments as a $1 / 3$ of the total volume, flow and permeability characteristics (Figure 7), even knowing that the surface area, permeability, and lengths of the segments of the digestive tract differed [27]. We found higher abundance P450 activity in the proximal region but higher localization of P-gp in the distal region; this pattern produced the lowest availability in drug absorption (Figure 8). This same trend was confirmed by Watanabe et al. [122] years later in a simulation study. The transporter distributions and functions along the intestinal segments reveal similar transporter and drug metabolizing enzyme distribution patterns along the small intestine for rodents and humans (Table 4). Therefore, the rat may be used to predict drug transport across the small intestine in humans. The same extrapolation, however, is not recommended for drug metabolizing enzymes due to the known species differences observed among animal species [123]. The TM- or SFM-PBPK models have been developed to encompass heterogeneity of transporters and enzymes for improved prediction of $\mathrm{PK}$, including polymorphism and sex differences in enzymes, and tease out contributions of intestine and liver in first-pass metabolism (Table 4). Other factors on the physiology of the GIT may also be considered. It is known that the duodenum is the shortest segment and is approximately $1 / 5$ and $1 / 7$ the lengths of the jejunum and ileum, respectively [28]. As shown by the transport of substrates in segments using chamber or single-pass segmental perfusion, drug permeability, revealed with use of a deconvolution-permeability model, is higher in the jejunum [124,125]. Moreover, the $\mathrm{pH}$ and transit times in the duodenum, jejunum and ileum differed [28]. Dressman et al. [3] described, in the continuous absorption model, that the GIT is a continuous tube with varying spatial properties on permeability and solubility and $\mathrm{pH}$, surface area, lengths, diameters, gastric emptying [4], highlighting the importance of gastric emptying time, small intestinal transit time, and effective surface area for absorption [5]. There are other models that accommodate variation in villi surface area, in drug permeability along the intestinal segment. $\mathrm{Wu}$ [126] applied the SSFM to examine enterohepatic circulation of glucuronides and found that the processes is affected by segmental distribution of enzymes. With accountability of segmental CYP and P-gp activities, reasonable absorption, efflux, and metabolism are observed for midazolam and compound S [25].

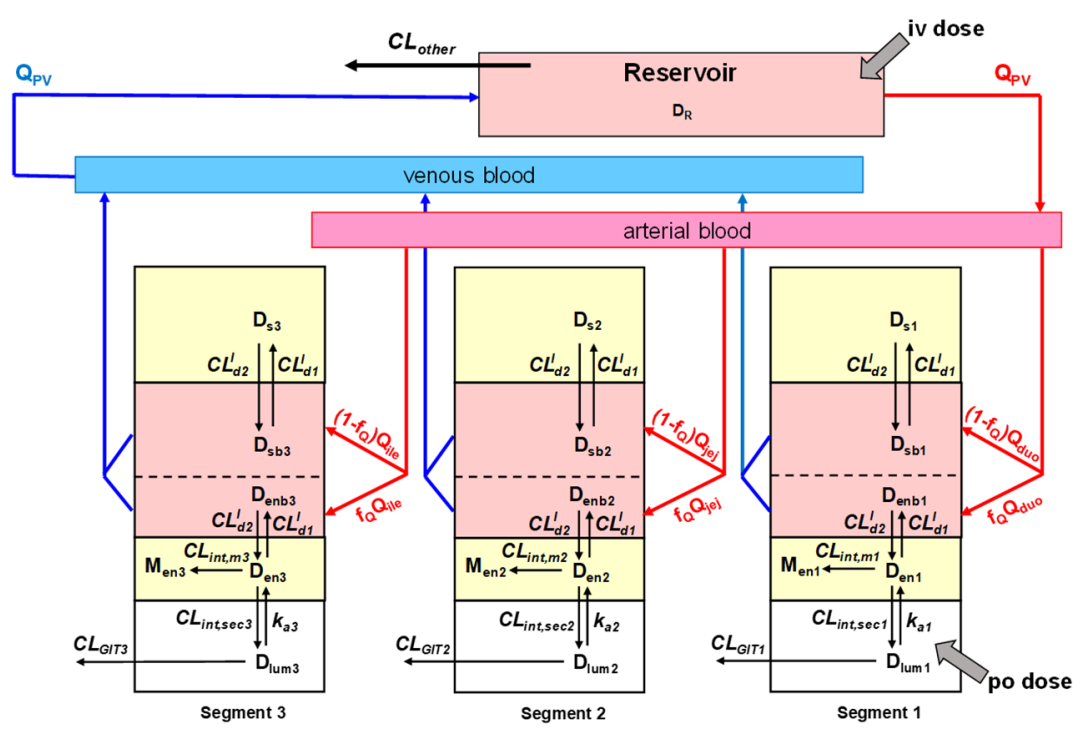

Figure 7. An expanded intestinal flow model—the segmental segregated flow PBPK model depicting the intestine as three different segmental regions with segregated flows to the enterocyte and serosal subcompartments. This figure was reproduced with permission from [121], ASPET, 2003. 


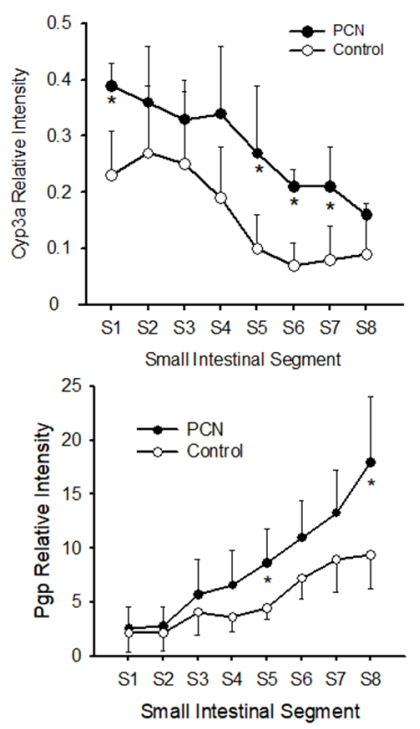

\section{Lowest $F_{1} \quad$ Highest $F_{1}$}

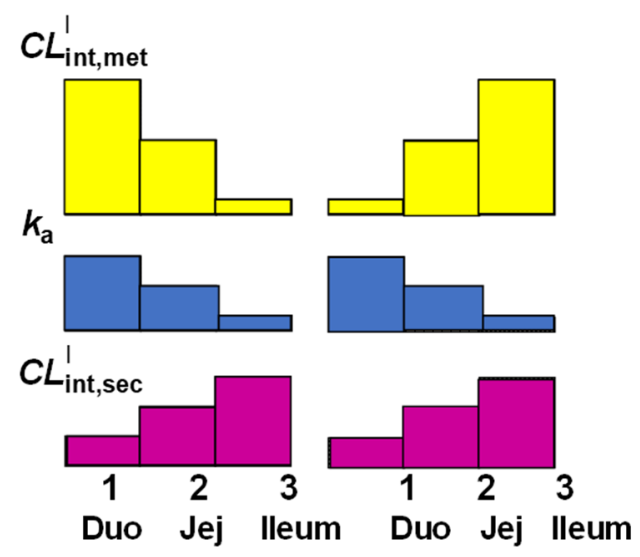

Figure 8. Heterogeneous distribution of Сyp3a and P-gp in the rat intestine, and changes accompanying the inducer, pregnenolone $16 \alpha$-carbonitrile (PCN) on intestinal bioavailablity. Both P-gp and Cyp3a relative protein expressions were determined by Western blotting (see referecne 26). The scale on the $y$-axes of the left panel represents an arbitray scale. Segments 1,2, 7, and 8 are the duodenal, proximal jejunal, distal jejunal and ileal segments, respectively. The symbols, duo and jej of the left panel denote the duodenum and jejunum, respectively. This figure was reproduced with permission from [26], ASPET, 2006.

Commercially available softwares on drug absorption include Simcyp ${ }^{\circledR}$ (advanced dissolution absorption metabolism (ADAM) model is implemented in Simcyp ${ }^{\circledR}$ ), GastroPlus and GI-Sim [127], and GUT framework [128], which tackle the subject of drug absorption. Although the same input parameters may be used, the software show different $F_{a}$ prediction characteristics depending on the rate-limiting steps of oral drug absorption [127]. The advanced compartmental absorption transit model or ACAT model [9], first conceived by Yu and Amidon [2] as the compartment absorption model [1], has evolved to include permeability (in silico properties derived from chemical structure), $\log \mathrm{P}, \mathrm{pKa}$, particle size and dose. Dissolution that is based on the Nernst-Brunner modification of the Noyes-Whitney equation is implemented. The influx and efflux transporters [129], $\mathrm{pH}$ and pKa, and heterogeneous enzyme distribution are recognized as important processes of the software $[2,10,11]$. Other considerations include the microbiota and composition. It appears that most of these models deal with dosage form and drug properties and may not have considered the segregated flow behavior of the intestine. A suggestion is for these software developers to consider first finalizing their software based on the absorption of a drug solution while incorporating flow and enzyme/transporter heterogeneity, then combining this to another model with the drug and intestine properties $(\log \mathrm{P}, \mathrm{pKa}$, particle size, $\mathrm{pH}$, surface area) to consider drug absorption.

Table 4. Heterogeneous distribution of enzymes and transporters in animal and human intestine.

\begin{tabular}{|c|c|c|}
\hline Transporter/Enzyme & Segmental Distribution & References \\
\hline \multicolumn{3}{|c|}{ Animals } \\
\hline $\begin{array}{l}\text { Apical sodium-dependent bile acid transporter } \\
\text { (Asbt) }\end{array}$ & $\begin{array}{c}\text { highest at ileum } \\
\text { duodenum }<\text { jejunum }<\text { ileum }\end{array}$ & {$[130,131]$} \\
\hline Nucleoside transporters (Cnt) & highest in jejunum & [132] \\
\hline Monocarboxylic acid transporter (Mct1) & duodenum $<$ jejunum $>$ ileum & {$[88]$} \\
\hline Organic cation transporter 1 (Oct1) & duodenum $<$ jejunum $<$ ileum & [133] \\
\hline
\end{tabular}


Table 4. Cont.

\begin{tabular}{|c|c|c|}
\hline Transporter/Enzyme & Segmental Distribution & References \\
\hline Organic cation transporter 3 (Oct3) & duodenum $<$ jejunum $<$ ileum & [133] \\
\hline Organic anion transporting polypeptide 3 (Oatp3) & highest in jejunum & [133] \\
\hline Oligopeptide transporter 1 (PepT1) & duodenum $>$ jejunum $>$ ileum & [133] \\
\hline Multidrug resistance-associated protein 2 (Mrp2) & duodenum $>$ jejunum $>$ ileum & [133] \\
\hline Multidrug resistance-associated protein 3 (Mrp 3) & duodenum $<$ jejunum $<$ ileum & [133] \\
\hline Multidrug resistance-associated protein 4 (Mrp 4) & duodenum $>$ ileum $>$ jejunum & [88] \\
\hline P-glycoprotein (P-gp) & duodenum $<$ jejunum $<$ ileum & [26] \\
\hline Organic solute transporter $\alpha-\beta($ Ost $\alpha, \beta)$ & duodenum $>$ jejunum $>$ ileum & [21] \\
\hline Cytochrome P450 3A (Сур3а) & duodenum $\sim$ jejunum $>$ ileum & {$[134,135]$} \\
\hline Estrone sulfatase & duodenum $>$ jejunum $>$ ileum & [136] \\
\hline Glutathione S-Transferase (Gst) & duodenum $\sim$ jejunum $>$ ileum & [137] \\
\hline UDP-Glucuronosyltransferase (Ugt) & duodenum $\sim$ jejunum $>$ ileum & [138] \\
\hline \multicolumn{3}{|c|}{ Humans } \\
\hline ASBT & duodenum $<$ ileum & [139] \\
\hline OATP2B1 & duodenum $<$ ileum & [140] \\
\hline PEPT1 & $\begin{array}{c}\text { slightly increasing } \\
\text { jejunum }>\text { ileum }>\text { duodenum } \\
\text { duodenum } \sim \text { ileum }\end{array}$ & {$[19,139]$} \\
\hline MCT1 & $\begin{array}{l}\text { slightly decreasing } \\
\text { duodenum }>\text { ileum }\end{array}$ & [19] \\
\hline $\begin{array}{l}\text { CNT11 } \\
\text { CNT2 }\end{array}$ & $\begin{array}{c}\text { even } \\
\text { duo }>\text { ileum }\end{array}$ & [138] \\
\hline OCT1 & even & [19] \\
\hline OCTN1 & duodenum $<$ ileum & [138] \\
\hline OCTN2 & even & {$[19,139]$} \\
\hline MRP3 & even & [19] \\
\hline P-gp & ileum $>$ jejunum $>$ proximal & {$[19,25,28,140]$} \\
\hline BCRP & $\begin{array}{c}\text { even } \\
\text { jejunum }>\text { ileum }>\text { duodenum }\end{array}$ & {$[19,55,141]$} \\
\hline $\begin{array}{l}\text { MRP2 mRNA } \\
\text { MRP1 protein } \\
\text { MRP2 protein }\end{array}$ & $\begin{array}{l}\text { slightly decreasing } \\
\text { proximal > distal } \\
\text { even }\end{array}$ & {$[19,142]$} \\
\hline $\begin{array}{c}\text { MRP1 to } 5 \\
\text { MRP2 to MRP6 } \\
\text { MRP4 }\end{array}$ & duodenum $<$ jejunum and ileum & {$[141,143,144]$} \\
\hline CYP3A4 & proximal $>$ distal & {$[25,28]$} \\
\hline $\begin{array}{l}\text { UGT1A1 } \\
\text { UGT1A3 } \\
\text { UGT1A4 } \\
\text { UGT1A5 } \\
\text { UGT1A6 } \\
\text { UGT1A7 } \\
\text { UGT1A8 } \\
\text { UGT1A9 } \\
\text { UGT1A10 } \\
\text { UGT2B4 } \\
\text { UGT2B7 } \\
\text { UGT2B10 } \\
\text { UGT2B15 }\end{array}$ & $\begin{array}{l}\text { duodenum } \sim \text { jejunum and ileum } \\
\text { duodenum }<\text { jejunum and ileum } \\
\text { duodenum } \sim \text { jejunum and ileum } \\
\text { duodenum } \sim \text { jejunum and ileum } \\
\text { duodenum }>\text { jejunum and ileum } \\
\text { duodenum } \sim \text { jejunum and ileum } \\
\text { duodenum } \sim \text { jejunum and ileum } \\
\text { duodenum } \sim \text { jejunum and ileum } \\
\text { duodenum and jejunum }>\text { ileum } \\
\text { duodenum and jejunum }<\text { ileum } \\
\text { duodenum and jejunum }<\text { ileum } \\
\text { duodenum and jejunum }<\text { ileum } \\
\text { duodenum }<\text { jejunum and ileum }\end{array}$ & [145] \\
\hline $\begin{array}{c}\text { SULT1A1, 1A3, 1B1, 1E1 } \\
\text { SULT2A1 }\end{array}$ & $\begin{array}{l}\text { jejunum < ileum } \\
\text { jejunum }>\text { ileum }\end{array}$ & [146] \\
\hline $\begin{array}{l}\text { GST } \\
\text { GST }\end{array}$ & $\begin{array}{l}\text { jejunum }>\text { ileum } \\
\text { jejunum } \sim \text { ileum }\end{array}$ & [147] \\
\hline
\end{tabular}

\section{Conclusions}

This review has highlighted that metabolite formation and DDIs of the intestine are not well predicted by the traditional intestinal flow model (TM) with respect to the routes of administration of 
drug and inhibitor. Instead, we recognize the importance of the segregated flow model (SFM) as the premier model to examine intestinal drug metabolism. The evidence in the literature is compelling in support of the SFM based on route-dependent intestinal metabolism. The higher propensity of inhibition with oral and not intravenous dosing is indisputable. Implementation of the SFM is just an additional intestinal compartment away, and this PBPK segregated intestinal flow model (SFM) should be expanded to encompass heterogeneity of transporters and enzymes (SSFM) for improved prediction of PK, including polymorphism and sex differences in enzymes to tease out contributions of intestine and liver in first-pass metabolism. This type of metabolism model could now be coupled with an absorption model to fully investigate the different aspects of $F_{a}, F_{I}$ and $F_{H}$. We encourage the use of the more "bottom-up" approach in PBPK modeling to provide mechanistic insight into intestinal metabolism/transport [148] by incorporating the SFM into the model. Another improvement could be made is when the $\mathrm{Q}_{\mathrm{SMA}}$ is not assumed to equal $\mathrm{Q}_{\mathrm{PV}}$. The difference in flow $\left(\mathrm{Q}_{\mathrm{PV}}-\mathrm{Q}_{\mathrm{SMA}}\right)$ is due to the venous returns from the coeliac and splenic arteries, and stomach and mesenteries. These venous returns would join that from the small intestine $\left(\mathrm{Q}_{\mathrm{SMA}}\right)$ and the hepatic arterial flow to perfuse the liver $[149,150]$.

Funding: This research received no external funding.

Acknowledgments: We thank Qi Joy Yang for discussion.

Conflicts of Interest: The authors declare no conflict of interest.

\section{References}

1. Yu, L.X.; Lipka, E.; Crison, J.R.; Amidon, G.L. Transport approaches to the biopharmaceutical design of oral drug delivery systems: Prediction of intestinal absorption. Adv. Drug Deliv. Rev. 1996, 19, 359-376. [CrossRef]

2. Yu, L.X.; Amidon, G.L. A compartmental absorption and transit model for estimating oral drug absorption. Int. J. Pharm. 1999, 186, 119-125. [CrossRef]

3. Dressman, J.B.; Thelen, K.; Jantratid, E. Towards quantitative prediction of oral drug absorption. Clin. Pharmacokinet. 2008, 47, 655-667. [CrossRef] [PubMed]

4. Willmann, S.; Schmitt, W.; Keldenich, J.; Dressman, J.B. A physiologic model for simulating gastrointestinal flow and drug absorption in rats. Pharm. Res. 2003, 20, 1766-1771. [CrossRef]

5. Willmann, S.; Edginton, A.N.; Dressman, J.B. Development and validation of a physiology-based model for the prediction of oral absorption in monkeys. Pharm. Res. 2007, 24, 1275-1282. [CrossRef]

6. Dahan, A.; West, B.T.; Amidon, G.L. Segmental-dependent membrane permeability along the intestine following oral drug administration: Evaluation of a triple single-pass intestinal perfusion (TSPIP) approach in the rat. Eur. J. Pharm. Sci. 2009, 36, 320-329. [CrossRef]

7. Dahan, A.; Amidon, G.L. Segmental dependent transport of low permeability compounds along the small intestine due to P-glycoprotein: The role of efflux transport in the oral absorption of bcs class iii drugs. Mol. Pharm. 2009, 6, 19-28. [CrossRef]

8. Dahan, A.; Miller, J.M.; Hilfinger, J.M.; Yamashita, S.; Yu, L.X.; Lennernäs, H.; Amidon, G.L. High-permeability criterion for BCS classification: Segmental/pH dependent permeability considerations. Mol. Pharm. 2010, 7, 1827-1834. [CrossRef]

9. Agoram, B.; Woltosz, W.S.; Bolger, M.B. Predicting the impact of physiological and biochemical processes on oral drug bioavailability. Adv. Drug Deliv. Rev. 2001, 50 (Suppl. 1), S41-S67. [CrossRef]

10. Daga, P.R.; Bolger, M.B.; Haworth, I.S.; Clark, R.D.; Martin, E.J. Physiologically based pharmacokinetic modeling in lead optimization. 1. Evaluation and adaptation of GastroPlus to predict bioavailability of medchem series. Mol. Pharm. 2018, 15, 821-830. [CrossRef]

11. Hens, B.; Bolger, M.B. Application of a dynamic fluid and $\mathrm{pH}$ model to simulate intraluminal and systemic concentrations of a weak base in GastroPlus ${ }^{\mathrm{TM}}$. J. Pharm. Sci. 2019, 108, 305-315. [CrossRef]

12. Tsuji, A.; Tamai, I. Carrier-mediated intestinal transport of drugs. Pharm. Res. 1996, 13, 963-977. [CrossRef] [PubMed] 
13. Adibi, S.A. The oligopeptide transporter (PEPT-1) in human intestine: Biology and function. Gastroenterology 1997, 113, 332-340. [CrossRef]

14. Zhang, L.; Brett, C.M.; Giacomini, K.M. Role of organic cation transporters in drug absorption and elimination. Ann. Rev. Pharmacol. Toxicol. 1998, 38, 431-460. [CrossRef]

15. Brandsch, M.; Knutter, I.; Leibach, F.H. The intestinal H+/peptide symporter PEPT1: Structure-affinity relationships. Eur. J. Pharm. Sci. 2004, 21, 53-60. [CrossRef]

16. Terada, T.; Inui, K. Peptide transporters: Structure, function, regulation and application for drug delivery. Curr. Drug Metab. 2004, 5, 85-94. [CrossRef] [PubMed]

17. Muller, J.; Keiser, M.; Drozdzik, M.; Oswald, S. Expression, regulation and function of intestinal drug transporters: An update. Biol. Chem. 2017, 398, 175-192. [CrossRef] [PubMed]

18. Noh, K.; Pang, K.S. Theoretical consideration of the properties of intestinal flow models on route-dependent drug removal: Segregated flow (SFM) vs. traditional (TM). Biopharm. Drug Dispos. 2019, 40, 195-213. [CrossRef] [PubMed]

19. Englund, G.; Rorsman, F.; Ronnblom, A.; Karlbom, U.; Lazorova, L.; Grasjo, J.; Kindmark, A.; Artursson, P. Regional levels of drug transporters along the human intestinal tract: Co-expression of ABC and SLC transporters and comparison with Caco-2 cells. Eur. J. Pharm. Sci. 2006, 29, 269-277. [CrossRef]

20. Greiner, B.; Eichelbaum, M.; Fritz, P.; Kreichgauer, H.P.; Von Richter, O.; Zundler, J.; Kroemer, H.K. The role of intestinal P-glycoprotein in the interaction of digoxin and rifampin. J. Clin. Investig. 1999, 104, 147-153. [CrossRef]

21. Dawson, P.A.; Hubbert, M.; Haywood, J.; Craddock, A.L.; Zerangue, N.; Christian, W.V.; Ballatori, N. The heteromeric organic solute transporter alpha-beta, Ost $\alpha$-Ost $\beta$, is an ileal basolateral bile acid transporter. J. Biol. Chem. 2005, 280, 6960-6968. [CrossRef] [PubMed]

22. Abbott, N.J.; Khan, E.U.; Rollinson, C.M.; Reichel, A.; Janigro, D.; Dombrowski, S.M.; Dobbie, M.S.; Begley, D.J. Drug resistance in epilepsy: The role of the blood-brain barrier. Novartis Found. Symp. 2002, 243, 38-47. [PubMed]

23. Fromm, M.F.; Kim, R.B.; Stein, C.M.; Wilkinson, G.R.; Roden, D.M. Inhibition of p-glycoprotein-mediated drug transport: A unifying mechanism to explain the interaction between digoxin and quinidine. Circulation 1999, 99, 552-557. [CrossRef] [PubMed]

24. Lin, J.H.; Chiba, M.; Chen, I.W.; Nishime, J.A.; DeLuna, F.A.; Yamazaki, M.; Lin, Y.J. Effect of dexamethasone on the intestinal first-pass metabolism of indinavir in rats: Evidence of cytochrome P-450 A and P-glycoprotein induction. Drug Metab. Dispos. 1999, 27, 1187-1193.

25. Bruyère, A.; Decleves, X.; Bouzom, F.; Ball, K.; Marques, C.; Treton, X.; Pocard, M.; Valleur, P.; Bouhnik, Y.; Panis, Y.; et al. Effect of variations in the amounts of P-glycoprotein (ABCB1), BCRP (ABCG2) and CYP3A4 along the human small intestine on PBPK models for predicting intestinal first pass. Mol. Pharm. 2010, 7 , 1596-1607. [CrossRef]

26. Liu, S.; Tam, D.; Chen, X.; Pang, K.S. P-glycoprotein and an unstirred water layer barring digoxin absorption in the vascularly perfused rat small intestine preparation: Induction studies with pregnenolone-16alpha-carbonitrile. Drug Metab. Dispos. 2006, 34, 1468-1479. [CrossRef]

27. Helander, H.F.; Fandriks, L. Surface area of the digestive tract-Revisited. Scand. J. Gastroenterol. 2014, 49, 681-689. [CrossRef]

28. Badhan, R.; Penny, J.; Galetin, A.; Houston, J.B. Methodology for development of a physiological model incorporating CYP3A and P-glycoprotein for the prediction of intestinal drug absorption. J. Pharm. Sci. 2009, 98, 2180-2197. [CrossRef]

29. Fisher, M.B.; Paine, M.F.; Strelevitz, T.J.; Wrighton, S.A. The role of hepatic and extrahepatic UDP-glucuronosyltransferases in human drug metabolism. Drug Metab. Rev. 2001, 33, 273-297. [CrossRef]

30. Mizuma, T. Intestinal glucuronidation metabolism may have a greater impact on oral bioavailability than hepatic glucuronidation metabolism in humans: A study with raloxifene, substrate for UGT1A1, 1A8, 1A9, and 1A10. Int. J. Pharm. 2009, 378, 140-141. [CrossRef]

31. Paine, M.F.; Hart, H.L.; Ludington, S.S.; Haining, R.L.; Rettie, A.E.; Zeldin, D.C. The human intestinal cytochrome P-450 "pie". Drug Metab. Dispos. 2006, 34, 880-886. [CrossRef] [PubMed]

32. Radominska-Pandya, A.; Little, J.M.; Pandya, J.T.; Tephly, T.R.; King, C.D.; Barone, G.W.; Raufman, J.P. UDP-glucuronosyltransferases in human intestinal mucosa. Biochim. Biophys. Acta 1998, 1394, 199-208. [CrossRef] 
33. Barter, Z.E.; Bayliss, M.K.; Beaune, P.H.; Boobis, A.R.; Carlile, D.J.; Edwards, R.J.; Houston, J.B.; Lake, B.G.; Lipscomb, J.C.; Pelkonen, O.R.; et al. Scaling factors for the extrapolation of in vivo metabolic drug clearance from in vitro data: Reaching a consensus on values of human microsomal protein and hepatocellularity per gram of liver. Curr. Drug Metab. 2007, 8, 33-45. [CrossRef]

34. Ito, K.; Houston, J.B. Prediction of human drug clearance from in vitro and preclinical data using physiologically based and empirical approaches. Pharm. Res. 2005, 22, 103-112. [CrossRef]

35. Shin, H.C.; Kim, H.R.; Cho, H.J.; Yi, H.; Cho, S.M.; Lee, D.G.; Abd El-Aty, A.M.; Kim, J.S.; Sun, D.; Amidon, G.L. Comparative gene expression of intestinal metabolizing enzymes. Biopharm. Drug Dispos. 2009, 30, 411-421. [CrossRef] [PubMed]

36. Bullingham, R.E.; Nicholls, A.J.; Kamm, B.R. Clinical pharmacokinetics of mycophenolate mofetil. Clin. Pharmacokinet. 1998, 34, 429-455. [CrossRef]

37. Inoue, H.; Yuki, G.; Yokota, H.; Kato, S. Bisphenol a glucuronidation and absorption in rat intestine. Drug Metab. Dispos. 2003, 31, 140-144. [CrossRef]

38. Iwamoto, K.; Klaassen, C.D. First-pass effect of nalorphine in rats. J. Pharmcol. Exp. Ther. 1977, 203, 365-376.

39. Kosaka, K.; Sakai, N.; Endo, Y.; Fukuhara, Y.; Tsuda-Tsukimoto, M.; Ohtsuka, T.; Kino, I.; Tanimoto, T.; Takeba, N.; Takahashi, M.; et al. Impact of intestinal glucuronidation on the pharmacokinetics of raloxifene. Drug Metab. Dispos. 2011, 39, 1495-1502. [CrossRef]

40. Tukey, R.H.; Strassburg, C.P. Genetic multiplicity of the human UDP-glucuronosyltransferases and regulation in the gastrointestinal tract. Mol. Pharmacol. 2001, 59, 405-414. [CrossRef]

41. Kemp, D.C.; Fan, P.W.; Stevens, J.C. Characterization of raloxifene glucuronidation in vitro: Contribution of intestinal metabolism to presystemic clearance. Drug Metab. Dispos. 2002, 30, 694-700. [CrossRef] [PubMed]

42. Thummel, K.E.; O'Shea, D.; Paine, M.F.; Shen, D.D.; Kunze, K.L.; Perkins, J.D.; Wilkinson, G.R. Oral first-pass elimination of midazolam involves both gastrointestinal and hepatic CYP3A-mediated metabolism. Clin. Pharmacol. Ther. 1996, 59, 491-502. [CrossRef]

43. De Waziers, I.; Cugnenc, P.H.; Yang, C.S.; Leroux, J.P.; Beaune, P.H. Cytochrome P 450 isoenzymes, epoxide hydrolase and glutathione transferases in rat and human hepatic and extrahepatic tissues. J. Pharmacol. Exp. Ther. 1990, 253, 387-394. [PubMed]

44. Ozer, N.; Erdemli, O.; Sayek, I.; Ozer, I. Resolution and kinetic characterization of glutathione S-transferases from human jejunal mucosa. Biochem. Med. Metab. Biol. 1990, 44, 142-150. [CrossRef]

45. Maiti, S.; Chen, G. Ethanol up-regulates phenol sulfotransferase (Sult1a1) and hydroxysteroid sulfotransferase (Sult2a1) in rat liver and intestine. Arch. Physiol. Biochem. 2015, 121, 68-74. [CrossRef]

46. Gibaldi, M.; Boyes, R.N.; Feldman, S. Influence of first-pass effect on availability of drugs on oral administration. J. Pharm. Sci. 1971, 60, 1338-1340. [CrossRef]

47. Chen, J.; Pang, K.S. Effect of flow on first-pass metabolism of drugs: Single pass studies on 4-methylumbelliferone conjugation in the serially perfused rat intestine and liver preparations. J. Pharmcol. Exp. Ther. 1997, 280, 24-31.

48. Hirayama, H.; Pang, K.S. First-pass metabolism of gentisamide: Influence of intestinal metabolism on hepatic formation of conjugates. Studies in the once-through vascularly perfused rat intestine-liver preparation. Drug Metab. Dispos. 1990, 18, 580-587.

49. Pang, K.S.; Chow, E.C.Y. Commentary: Theoretical predictions of flow effects on intestinal and systemic availability in physiologically based pharmacokinetic intestine models: The traditional model, segregated flow model, and $Q_{\text {Gut }}$ model. Drug Metab. Dispos. 2012, 40, 1869-1877. [CrossRef]

50. Pang, K.S.; Mulder, G.J. The effect of hepatic blood flow on formation of metabolites. Drug Metab. Dispos. 1990, 18, 270-275.

51. Pang, K.S.; Han, Y.R.; Noh, K.; Lee, P.I.; Rowland, M. Hepatic clearance concepts and misconceptions: Why the well-stirred model is still used even though it is not physiologic reality? Biochem. Pharmacol. 2019, 169, 113596. [CrossRef]

52. Pang, K.S.; Rowland, M. Hepatic clearance of drugs. I. Theoretical considerations of a "well-stirred" model and a "parallel tube" model. Influence of hepatic blood flow, plasma and blood cell binding, and the hepatocellular enzymatic activity on hepatic drug clearance. J. Pharmacokinet. Biopharm. 1977, 5, 625-653. [CrossRef]

53. Roberts, M.S.; Rowland, M. A dispersion model of hepatic elimination: 1. Formulation of the model and bolus considerations J. Pharmacokinet. Biopharm. 1986, 14, 227-260. [CrossRef] [PubMed] 
54. Chapron, B.; Risler, L.; Phillips, B.; Collins, C.; Thummel, K.; Shen, D. Reversible, time-dependent inhibition of CYP3A-mediated metabolism of midazolam and tacrolimus by telaprevir in human liver microsomes. $J$. Pharm. Pharm. Sci. 2015, 18, 101-111. [CrossRef] [PubMed]

55. Guo, H.; Liu, C.; Li, J.; Zhang, M.; Hu, M.; Xu, P.; Liu, L.; Liu, X. A mechanistic physiologically based pharmacokinetic-enzyme turnover model involving both intestine and liver to predict CYP3A induction-mediated drug-drug interactions. J. Pharm. Sci. 2013, 102, 2819-2836. [CrossRef] [PubMed]

56. Shirasaka, Y.; Chang, S.Y.; Grubb, M.F.; Peng, C.C.; Thummel, K.E.; Isoherranen, N.; Rodrigues, A.D. Effect of CYP3A5 expression on the inhibition of CYP3A-catalyzed drug metabolism: Impact on modeling cyp3a-mediated drug-drug interactions. Drug Metab. Dispos. 2013, 41, 1566-1574. [CrossRef]

57. Tsunoda, S.M.; Velez, R.L.; Von Moltke, L.L.; Greenblatt, D.J. Differentiation of intestinal and hepatic cytochrome P4503A activity with use of midazolam as an in vivo probe: Effect of ketoconazole. Clin. Pharmacol. Ther. 1999, 66, 461-471. [CrossRef]

58. Wang, J.S.; Wen, X.; Backman, J.T.; Taavitsainen, P.; Neuvonen, P.J.; Kivisto, K.T. Midazolam alpha-hydroxylation by human liver microsomes in vitro: Inhibition by calcium channel blockers, itraconazole and ketoconazole. Pharmacol. Toxicol. 1999, 85, 157-161. [CrossRef]

59. Paine, M.F.; Shen, D.D.; Kunze, K.L.; Perkins, J.D.; Marsh, C.L.; McVicar, J.P.; Barr, D.M.; Gillies, B.S.; Thummel, K.E. First-pass metabolism of midazolam by the human intestine. Clin. Pharmacol. Ther. 1996, 60, 14-24. [CrossRef]

60. Lown, K.S.; Thummel, K.E.; Benedict, P.E.; Shen, D.D.; Turgeon, D.K.; Berent, S.; Watkins, P.B. The erythromycin breath test predicts the clearance of midazolam. Clin. Pharmacol. Ther. 1995, 57, 16-24. [CrossRef]

61. Doherty, M.M.; Pang, K.S. Route-dependent metabolism of morphine in the vascularly perfused rat small intestine preparation. Pharm. Res. 2000, 17, 291-298. [CrossRef] [PubMed]

62. Pang, K.S.; Cherry, W.F.; Ulm, E.H. Disposition of enalapril in the perfused rat intestine-liver preparation: Absorption, metabolism and first-pass effect. J. Pharmacol. Exp. Ther. 1985, 233, 788-795. [PubMed]

63. Pang, K.S.; Yuen, V.; Fayz, S.; Te Koppele, J.M.; Mulder, G.J. Absorption and metabolism of acetaminophen by the in situ perfused rat small intestine preparation. Drug Metab. Dispos. 1986, 14, 102-111.

64. Wen, Y.; Remmel, R.P.; Zimmerman, C.L. First-pass disposition of (-)-6-aminocarbovir in rats. I. Prodrug activation may be limited by access to enzyme. Drug Metab. Dispos. 1999, 27, 113-121.

65. Sahali-Sahly, Y.; Balani, S.K.; Lin, J.H.; Baillie, T.A. In vitro studies on the metabolic activation of the furanopyridine 1-754,394, a highly potent and selective mechanism-based inhibitor of cytochrome P450 3A4. Chem. Res. Toxicol. 1996, 9, 1007-1012. [CrossRef] [PubMed]

66. Ducharme, M.P.; Warbasse, L.H.; Edwards, D.J. Disposition of intravenous and oral cyclosporine after administration with grapefruit juice. Clin. Pharmacol. Ther. 1995, 57, 485-491. [CrossRef]

67. Darbar, D.; Fromm, M.F.; Dell'Orto, S.; Kim, R.B.; Kroemer, H.K.; Eichelbaum, M.; Roden, D.M. Modulation by dietary salt of verapamil disposition in humans. Circulation 1998, 98, 2702-2708. [CrossRef]

68. Talseth, T. Studies on hydralazine. III. Bioavailability of hydralazine in man. Eur. J. Clin. Pharmacol. 1976, 10, 395-401. [CrossRef] [PubMed]

69. Till, A.E.; Constanzer, M.L.; Demetriades, J.; Irvin, J.D.; Lee, R.B.; Ferguson, R.K. Evidence for route dependent biotransformation of cyclobenzaprine hydrochloride. Biopharm. Drug Dispos. 1982, 3, 19-28. [CrossRef]

70. Paine, M.F.; Khalighi, M.; Fisher, J.M.; Shen, D.D.; Kunze, K.L.; Marsh, C.L.; Perkins, J.D.; Thummel, K.E. Characterization of interintestinal and intraintestinal variations in human CYP3A-dependent metabolism. J. Pharmacol. Exp. Ther. 1997, 283, 1552-1562.

71. Kwan, K.C.; Foltz, E.L.; Breault, G.O.; Baer, J.E.; Totaro, J.A. Pharmacokinetics of methyldopa in man. J. Pharmacol. Exp. Ther. 1976, 198, 264-277. [PubMed]

72. Darbar, D.; Dell'Orto, S.; Morike, K.; Wilkinson, G.R.; Roden, D.M. Dietary salt increases first-pass elimination of oral quinidine. Clin. Pharmacol. Ther. 1997, 61, 292-300. [CrossRef]

73. Mano, Y.; Sugiyama, Y.; Ito, K. Use of a physiologically based pharmacokinetic model for quantitative prediction of drug-drug interactions via CYP3A4 and estimation of the intestinal availability of CYP3A4 substrates. J. Pharm. Sci. 2015, 104, 3183-3193. [CrossRef] [PubMed]

74. Marzolini, C.; Rajoli, R.; Battegay, M.; Elzi, L.; Back, D.; Siccardi, M. Physiologically based pharmacokinetic modeling to predict drug-drug interactions with efavirenz involving simultaneous inducing and inhibitory effects on cytochromes. Clin. Pharmacokinet. 2017, 56, 409-420. [CrossRef] 
75. Quinney, S.K.; Galinsky, R.E.; Jiyamapa-Serna, V.A.; Chen, Y.; Hamman, M.A.; Hall, S.D.; Kimura, R.E. Hydroxyitraconazole, formed during intestinal first-pass metabolism of itraconazole, controls the time course of hepatic CYP3A inhibition and the bioavailability of itraconazole in rats. Drug Metab. Dispos. 2008, 36, 1097-1101. [CrossRef]

76. Yang, Q.J.; Fan, J.; Chen, S.; Liu, L.; Sun, H.; Pang, K.S. Metabolite kinetics: The segregated flow model for intestinal and whole body physiologically based pharmacokinetic modeling to describe intestinal and hepatic glucuronidation of morphine in rats in vivo. Drug Metab. Dispos. 2016, 44, 1123-1138. [CrossRef]

77. Noh, K.; Chen, S.; Yang, Q.J.; Pang, K.S. Physiologically based pharmacokinetic modeling revealed minimal codeine intestinal metabolism in first-pass removal in rats. Biopharm. Drug Dispos. 2017, 38, 50-74. [CrossRef]

78. Zhang, X.; Quinney, S.K.; Gorski, J.C.; Jones, D.R.; Hall, S.D. Semiphysiologically based pharmacokinetic models for the inhibition of midazolam clearance by diltiazem and its major metabolite. Drug Metab. Dispos. 2009, 37, 1587-1597. [CrossRef]

79. Klippert, P.J.M.; Noordhoek, J. Influence of administration route and blood sampling site on the area under the curve. Assessment of gut wall, liver, and lung metabolism from a physiological model. Drug Metab. Dispos. 1983, 11, 62-66.

80. Cong, D.; Doherty, M.; Pang, K.S. A new physiologically based, segregated-flow model to explain route-dependent intestinal metabolism. Drug Metab. Dispos. 2000, 28, 224-235.

81. Gertz, M.; Harrison, A.; Houston, J.B.; Galetin, A. Prediction of human intestinal first-pass metabolism of 25 CYP3A substrates from in vitro clearance and permeability data. Drug Metab. Dispos. 2010, 38, 1147-1158. [CrossRef] [PubMed]

82. Gertz, M.; Houston, J.B.; Galetin, A. Physiologically based pharmacokinetic modeling of intestinal first-pass metabolism of CYP3A substrates with high intestinal extraction. Drug Metab. Dispos. 2011, 39, 1633-1642. [CrossRef] [PubMed]

83. Yang, J.; Jamei, M.; Yeo, K.R.; Tucker, G.T.; Rostami-Hodjegan, A. Prediction of intestinal first-pass drug metabolism. Curr. Drug Metab. 2007, 8, 676-684. [CrossRef] [PubMed]

84. Sun, H.; Pang, K.S. Physiological modeling to understand the impact of enzymes and transporters on drug and metabolite data and bioavailability estimates. Pharm. Res. 2010, 27, 1237-1254. [CrossRef]

85. Svanvik, J. Mucosal blood circulation and its influence on passive absorption in the small intestine. An experimental study in the cat. Acta Physiol. Scand. Suppl. 1973, 385, 1-44.

86. Granger, D.N.; Richardson, P.D.; Kvietys, P.R.; Mortillaro, N.A. Intestinal blood flow. Gastroenterology 1980, 78, 837-863. [CrossRef]

87. Yang, Q.J.; Bukuroshi, P.; Quach, H.P.; Chow, E.C.Y.; Pang, K.S. Highlighting vitamin D receptor-targeted activities of $1 \alpha, 25$-dihydroxyvitamin $\mathrm{D}_{3}$ in mice via physiologically based pharmacokinetic-pharmacodynamic modeling. Drug Metab. Dispos. 2018, 46, 75-87. [CrossRef]

88. Cong, D.; Fong, A.K.; Lee, R.; Pang, K.S. Absorption of benzoic acid in segmental regions of the vascularly perfused rat small intestine preparation. Drug Metab. Dispos. 2001, 29, 1539-1547.

89. Chow, E.C.; Durk, M.R.; Cummins, C.L.; Pang, K.S. $1 \alpha, 25$-Dihydroxyvitamin $D_{3}$ upregulates P-glycoprotein activities via the vitamin $\mathrm{D}$ receptor and not farnesoid $\mathrm{X}$ receptor in both $f \times r(-/)$ and $f x r(+/+)$ mice, and increased renal and brain efflux of digoxin in mice in vivo. J. Pharmacol. Exp. Ther. 2011, 337, 846-859. [CrossRef]

90. Ogasawara, A.; Utoh, M.; Nii, K.; Ueda, A.; Yoshikawa, T.; Kume, T.; Fukuzaki, K. Effect of oral ketoconazole on oral and intravenous pharmacokinetics of simvastatin and its acid in cynomolgus monkeys. Drug Metab. Dispos. 2009, 37, 122-128. [CrossRef]

91. Eeckhoudt, S.L.; Horsmans, Y.; Verbeeck, R.K. Differential induction of midazolam metabolism in the small intestine and liver by oral and intravenous dexamethasone pretreatment in rat. Xenobiotica 2002, 32, 975-984. [CrossRef]

92. Song, X.; Ju, Y.; Zhao, H.; Qiu, W. Effect of purple grape juice on the pharmacokinetics of digoxin: Results of a food-drug interaction study. Int. J. Clin. Pharmacol. Ther. 2019, 57, 101-109. [CrossRef] [PubMed]

93. Westphal, K.; Weinbrenner, A.; Zschiesche, M.; Franke, G.; Knoke, M.; Oertel, R.; Fritz, P.; Von Richter, O.; Warzok, R.; Hachenberg, T.; et al. Induction of P-glycoprotein by rifampin increases intestinal secretion of talinolol in human beings: A new type of drug/drug interaction. Clin. Pharmacol. Ther. 2000, 68, 345-355. [CrossRef] [PubMed] 
94. Hebert, M.F.; Fisher, R.M.; Marsh, C.L.; Dressler, D.; Bekersky, I. Effects of rifampin on tacrolimus pharmacokinetics in healthy volunteers. J. Clin. Pharmacol. 1999, 39, 91-96. [CrossRef] [PubMed]

95. Boni, J.; Leister, C.; Burns, J.; Cincotta, M.; Hug, B.; Moore, L. Pharmacokinetic profile of temsirolimus with concomitant administration of cytochrome P450-inducing medications. J. Clin. Pharmacol. 2007, 47, 1430-1439. [CrossRef] [PubMed]

96. Dong, J.; Yu, X.; Wang, L.; Sun, Y.B.; Chen, X.J.; Wang, G.J. Effects of cyclosporin a and itraconazole on the pharmacokinetics of atorvastatin in rats. Acta Pharmacol. Sin. 2008, 29, 1247-1252. [CrossRef]

97. Amioka, K.; Kuzuya, T.; Kushihara, H.; Ejiri, M.; Nitta, A.; Nabeshima, T. Carvedilol increases ciclosporin bioavailability by inhibiting P-glycoprotein-mediated transport. J. Pharm. Pharmacol. 2007, 59, 1383-1387. [CrossRef]

98. Gomez, D.Y.; Wacher, V.J.; Tomlanovich, S.J.; Hebert, M.F.; Benet, L.Z. The effects of ketoconazole on the intestinal metabolism and bioavailability of cyclosporine. Clin. Pharmacol. Ther. 1995, 58, 15-19. [CrossRef]

99. Lundahl, J.; Regardh, C.G.; Edgar, B.; Johnsson, G. Effects of grapefruit juice ingestion-Pharmacokinetics and haemodynamics of intravenously and orally administered felodipine in healthy men. Eur. J. Clin. Pharmacol. 1997, 52, 139-145. [CrossRef]

100. Yang, S.H.; Cho, Y.A.; Choi, J.S. Effects of ticlopidine on pharmacokinetics of losartan and its main metabolite exp-3174 in rats. Acta Pharmacol. Sin. 2011, 32, 967-972. [CrossRef]

101. Gorski, J.C.; Jones, D.R.; Haehner-Daniels, B.D.; Hamman, M.A.; O'Mara, E.M., Jr.; Hall, S.D. The contribution of intestinal and hepatic CYP3A to the interaction between midazolam and clarithromycin. Clin. Pharmacol. Ther. 1998, 64, 133-143. [CrossRef]

102. Kupferschmidt, H.H.; Ha, H.R.; Ziegler, W.H.; Meier, P.J.; Krahenbuhl, S. Interaction between grapefruit juice and midazolam in humans. Clin. Pharmacol. Ther. 1995, 58, 20-28. [CrossRef]

103. Olkkola, K.T.; Ahonen, J.; Neuvonen, P.J. The effects of the systemic antimycotics, itraconazole and fluconazole, on the pharmacokinetics and pharmacodynamics of intravenous and oral midazolam. Anesth. Anal. 1996, $82,511-516$.

104. Olkkola, K.T.; Aranko, K.; Luurila, H.; Hiller, A.; Saarnivaara, L.; Himberg, J.J.; Neuvonen, P.J. A potentially hazardous interaction between erythromycin and midazolam. Clin. Pharmacol. Ther. 1993, 53, 298-305. [CrossRef] [PubMed]

105. Palkama, V.J.; Ahonen, J.; Neuvonen, P.J.; Olkkola, K.T. Effect of saquinavir on the pharmacokinetics and pharmacodynamics of oral and intravenous midazolam. Clin. Pharmacol. Ther. 1999, 66, 33-39. [CrossRef]

106. Saari, T.I.; Laine, K.; Leino, K.; Valtonen, M.; Neuvonen, P.J.; Olkkola, K.T. Effect of voriconazole on the pharmacokinetics and pharmacodynamics of intravenous and oral midazolam. Clin. Pharmacol. Ther. 2006, 79, 362-370. [CrossRef]

107. Choi, J.S.; Choi, J.S.; Choi, D.H. Effects of licochalcone a on the bioavailability and pharmacokinetics of nifedipine in rats: Possible role of intestinal CYP3A4 and P-gp inhibition by licochalcone a. Biopharm. Drug Dispos. 2014, 35, 382-390. [CrossRef]

108. Rashid, T.J.; Martin, U.; Clarke, H.; Waller, D.G.; Renwick, A.G.; George, C.F. Factors affecting the absolute bioavailability of nifedipine. Br. J. Clin. Pharmacol. 1995, 40, 51-58. [CrossRef]

109. Kupferschmidt, H.H.; Fattinger, K.E.; Ha, H.R.; Follath, F.; Krahenbuhl, S. Grapefruit juice enhances the bioavailability of the hiv protease inhibitor saquinavir in man. Br. J. Clin. Pharmacol. 1998, 45, 355-359. [CrossRef]

110. Floren, L.C.; Bekersky, I.; Benet, L.Z.; Mekki, Q.; Dressler, D.; Lee, J.W.; Roberts, J.P.; Hebert, M.F. Tacrolimus oral bioavailability doubles with coadministration of ketoconazole. Clin. Pharmacol. Ther. 1997, 62, 41-49. [CrossRef]

111. Harwood, M.D.; Neuhoff, S.; Carlson, G.L.; Warhurst, G.; Rostami-Hodjegan, A. Absolute abundance and function of intestinal drug transporters: A prerequisite for fully mechanistic in vitro-in vivo extrapolation of oral drug absorption. Biopharm. Drug Dispos. 2013, 34, 2-28. [CrossRef]

112. Kadono, K.; Akabane, T.; Tabata, K.; Gato, K.; Terashita, S.; Teramura, T. Quantitative prediction of intestinal metabolism in humans from a simplified intestinal availability model and empirical scaling factor. Drug Metab. Dispos. 2010, 38, 1230-1237. [CrossRef] [PubMed] 
113. Glaeser, H.; Drescher, S.; Van der Kuip, H.; Behrens, C.; Geick, A.; Burk, O.; Dent, J.; Somogyi, A.; Von Richter, O.; Griese, E.U.; et al. Shed human enterocytes as a tool for the study of expression and function of intestinal drug-metabolizing enzymes and transporters. Clin. Pharmacol. Ther. 2002, 71, 131-140. [CrossRef] [PubMed]

114. Von Richter, O.; Burk, O.; Fromm, M.F.; Thon, K.P.; Eichelbaum, M.; Kivisto, K.T. Cytochrome P450 3A4 and P-glycoprotein expression in human small intestinal enterocytes and hepatocytes: A comparative analysis in paired tissue specimens. Clin. Pharmacol. Ther. 2004, 75, 172-183. [CrossRef] [PubMed]

115. Nishimuta, H.; Sato, K.; Yabuki, M.; Komuro, S. Prediction of the intestinal first-pass metabolism of CYP3A and UGT substrates in humans from in vitro data. Drug Metab. Pharmacokinet. 2011, 26, 592-601. [CrossRef]

116. Tam, D.; Tirona, R.G.; Pang, K.S. Segmental intestinal transporters and metabolic enzymes on intestinal drug absorption. Drug Metab. Dispos. 2003, 31, 373-383. [CrossRef]

117. Watanabe, T.; Maeda, K.; Nakai, C.; Sugiyama, Y. Investigation of the effect of the uneven distribution of CYP3A4 and P-glycoprotein in the intestine on the barrier function against xenobiotics: A simulation study. J. Pharm. Sci. 2013, 102, 3196-3204. [CrossRef]

118. Cao, X.; Gibbs, S.T.; Fang, L.; Miller, H.A.; Landowski, C.P.; Shin, H.C.; Lennernäs, H.; Zhong, Y.; Amidon, G.L.; $\mathrm{Yu}, \mathrm{L} . X . ;$ et al. Why is it challenging to predict intestinal drug absorption and oral bioavailability in human using rat model. Pharm. Res. 2006, 23, 1675-1686. [CrossRef]

119. Chen, X.; Chen, F.; Liu, S.; Glaeser, H.; Dawson, P.A.; Hofmann, A.F.; Kim, R.B.; Shneider, B.L.; Pang, K.S. Transactivation of rat apical sodium-dependent bile acid transporter and increased bile acid transport by $1 \alpha$,25-dihydroxyvitamin $\mathrm{D}_{3}$ via the vitamin d receptor. Mol. Pharmacol. 2006, 69, 1913-1923. [CrossRef]

120. Mottino, A.D.; Hoffman, T.; Dawson, P.A.; Luquita, M.G.; Monti, J.A.; Sanchez Pozzi, E.J.; Catania, V.A.; Cao, J.; Vore, M. Increased expression of ileal apical sodium-dependent bile acid transporter in postpartum rats. Am. J. Physiol. Gastrointest. Liver Physiol. 2002, 282, G41-G50. [CrossRef]

121. Ngo, L.Y.; Patil, S.D.; Unadkat, J.D. Ontogenic and longitudinal activity of $\mathrm{Na}(+)$-nucleoside transporters in the human intestine. Am. J. Physiol. Gastrointest. Liver Physiol. 2001, 280, G475-G481. [CrossRef] [PubMed]

122. Chow, E.C.; Sun, H.; Khan, A.A.; Groothuis, G.M.; Pang, K.S. Effects of $1 \alpha, 25$-dihydroxyvitamin $\mathrm{D}_{3}$ on transporters and enzymes of the rat intestine and kidney in vivo. Biopharm. Drug Dispos. 2010, 31, 91-108. [PubMed]

123. Liu, B.; Crewe, H.K.; Ozdemir, M.; Rowland Yeo, K.; Tucker, G.; Rostami-Hodjegan, A. The absorption kinetics of ketoconazole plays a major role in explaining the reported variability in the level of interaction with midazolam: Interplay between formulation and inhibition of gut wall and liver metabolism. Biopharm. Drug Dispos. 2017, 38, 260-270. [CrossRef] [PubMed]

124. Bolger, M.B.; Lukacova, V.; Woltosz, W.S. Simulations of the nonlinear dose dependence for substrates of influx and efflux transporters in the human intestine. AAPS J. 2009, 11, 353-363. [CrossRef] [PubMed]

125. Jones, H.M.; Chen, Y.; Gibson, C.; Heimbach, T.; Parrott, N.; Peters, S.A.; Snoeys, J.; Upreti, V.V.; Zheng, M.; Hall, S.D. Physiologically based pharmacokinetic modeling in drug discovery and development: A pharmaceutical industry perspective. Clin. Pharmacol. Ther. 2015, 97, 247-262. [CrossRef]

126. Jamei, M.; Bajot, F.; Neuhoff, S.; Barter, Z.; Yang, Z.; Rostami-Hodjegan, A.; Rowland-Yeo, K. A mechanistic framework for in vitro-in vivo extrapolation of liver membrane transporters: Ppion of drug-drug interaction between rosuvastatin and cyclosporine. Clin. Pharmacokinet. 2014, 53, 73-87. [CrossRef] [PubMed]

127. Bi, Y.; Deng, J.; Murry, D.J.; An, G. Awhole-body physiologically based pharmacokinetic model of gefitinib in mice and scale-up to humans. AAPS J. 2015, 18. [CrossRef]

128. Kharasch, E.D.; Walker, A.; Hoffer, C.; Sheffels, P. Intravenous and oral alfentanil as in vivo probes for hepatic and first-pass cytochrome P450 3A activity: Noninvasive assessment by use of pupillary miosis. Clin. Pharmacol. Ther. 2004, 76, 452-466. [CrossRef] [PubMed]

129. Hebert, M.F.; Roberts, J.P.; Prueksaritanont, T.; Benet, L.Z. Bioavailability of cyclosporine with concomitant rifampin administration is markedly less than predicted by hepatic enzyme induction. Clin. Pharmacol. Ther. 1992, 52, 453-457. [CrossRef]

130. Mitschke, D.; Reichel, A.; Fricker, G.; Moenning, U. Characterization of cytochrome p450 protein expression along the entire length of the intestine of male and female rats. Drug Metab. Dispos. 2008, 36, 1039-1045. [CrossRef]

131. Huijghebaert, S.M.; Sim, S.M.; Back, D.J.; Eyssen, H.J. Distribution of estrone sulfatase activity in the intestine of germfree and conventional rats. J. Steroid Biochem. 1984, 20, 1175-1179. [CrossRef] 
132. Pinkus, L.M.; Ketley, J.N.; Jakoby, W.B. The glutathione S-transferases as a possible detoxification system of rat intestinal epithelium. Biochem. Pharmacol. 1977, 26, 2359-2363. [CrossRef]

133. Koster, A.S.; Frankhuijzen-Sierevogel, A.C.; Noordhoek, J. Glucuronidation of morphine and six beta 2-sympathomimetics in isolated rat intestinal epithelial cells. Drug Metab. Dispos. 1985, 13, 232-238. [PubMed]

134. Meier, Y.; Eloranta, J.J.; Darimont, J.; Ismair, M.G.; Hiller, C.; Fried, M.; Kullak-Ublick, G.A.; Vavricka, S.R. Regional distribution of solute carrier mRNA expression along the human intestinal tract. Drug Metab. Dispos. 2007, 35, 590-594. [CrossRef]

135. Mouly, S.; Paine, M.F. P-glycoprotein increases from proximal to distal regions of human small intestine. Pharm. Res. 2003, 20, 1595-1599. [CrossRef]

136. Haslam, I.S.; Wright, J.A.; O’Reilly, D.A.; Sherlock, D.J.; Coleman, T.; Simmons, N.L. Intestinal ciprofloxacin efflux: The role of breast cancer resistance protein (ABCG2). Drug Metab. Dispos. 2011, 39, 2321-2328. [CrossRef]

137. Berggren, S.; Gall, C.; Wollnitz, N.; Ekelund, M.; Karlbom, U.; Hoogstraate, J.; Schrenk, D.; Lennernäs, H. Gene and protein expression of P-glycoprotein, MRP1, MRP2, and CYP3A4 in the small and large human intestine. Mol. Pharm. 2007, 4, 252-257. [CrossRef]

138. Prime-Chapman, H.M.; Fearn, R.A.; Cooper, A.E.; Moore, V.; Hirst, B.H. Differential multidrug resistance-associated protein 1 through 6 isoform expression and function in human intestinal epithelial Caco-2 cells. J. Pharmacol. Exp. Ther. 2004, 311, 476-484. [CrossRef]

139. Zimmermann, C.; Gutmann, H.; Hruz, P.; Gutzwiller, J.P.; Beglinger, C.; Drewe, J. Mapping of multidrug resistance gene 1 and multidrug resistance-associated protein isoform 1 to $5 \mathrm{mRNA}$ expression along the human intestinal tract. Drug Metab. Dispos. 2005, 33, 219-224. [CrossRef]

140. Strassburg, C.P.; Kneip, S.; Topp, J.; Obermayer-Straub, P.; Barut, A.; Tukey, R.H.; Manns, M.P. Polymorphic gene regulation and interindividual variation of UDP-glucuronosyltransferase activity in human small intestine. J. Biol. Chem. 2000, 275, 36164-36171. [CrossRef] [PubMed]

141. Teubner, W.; Meinl, W.; Florian, S.; Kretzschmar, M.; Glatt, H. Identification and localization of soluble sulfotransferases in the human gastrointestinal tract. Biochem. J. 2007, 404, 207-215. [CrossRef] [PubMed]

142. Khuruna, S.; Corbally, M.T.; Manning, F.; Armenise, T.; Kierce, B.; Kitty, C. Glutathione S-transferase: A potential new marker of intestinal ischemia. J. Pediatr. Surg. 2002, 37, 1543-1548. [CrossRef] [PubMed]

143. Dahlgren, D.; Lennernäs, H. Intestinal permeability and drug absorption: Predictive experimental, computational and in vivo approaches. Pharmaceutics 2019, 11, 411. [CrossRef] [PubMed]

144. Dahlgren, D.; Roos, C.; Lundqvist, A.; Abrahamsson, B.; Tannergren, C.; Hellstrom, P.M.; Sjögren, E.; Lennernäs, H. Regional intestinal permeability of three model drugs in human. Mol. Pharm. 2016, 13, 3013-3021. [CrossRef] [PubMed]

145. Wu, B. Use of physiologically based pharmacokinetic models to evaluate the impact of intestinal glucuronide hydrolysis on the pharmacokinetics of aglycone. J. Pharm. Sci. 2012, 101, 1281-1301. [CrossRef] [PubMed]

146. Sjögren, E.; Thorn, H.; Tannergren, C. In silico modeling of gastrointestinal drug absorption: Predictive performance of three physiologically based absorption models. Mol. Pharm. 2016, 13, 1763-1778. [CrossRef]

147. Matsumura, N.; Hayashi, S.; Akiyama, Y.; Ono, A.; Funaki, S.; Tamura, N.; Kimoto, T.; Jiko, M.; Haruna, Y.; Sarashina, A.; et al. Prediction characteristics of oral absorption simulation software evaluated using structurally diverse low-solubility drugs. J. Pharm. Sci. 2019, 109, 1403-1416. [CrossRef]

148. Kharasch, E.D.; Hoffer, C.; Whittington, D.; Sheffels, P. Role of hepatic and intestinal cytochrome P450 3A and 2B6 in the metabolism, disposition, and miotic effects of methadone. Clin. Pharmacol. Ther. 2004, 76, 250-269. [CrossRef]

149. Gorski, J.C.; Vannaprasaht, S.; Hamman, M.A.; Ambrosius, W.T.; Bruce, M.A.; Haehner-Daniels, B.; Hall, S.D. The effect of age, sex, and rifampin administration on intestinal and hepatic cytochrome P450 3A activity. Clin. Pharmacol. Ther. 2003, 74, 275-287. [CrossRef]

150. Holtbecker, N.; Fromm, M.F.; Kroemer, H.K.; Ohnhaus, E.E.; Heidemann, H. The nifedipine-rifampin interaction. Evidence for induction of gut wall metabolism. Drug Metab. Dispos. 1996, 24, 1121-1123.

(C) 2020 by the authors. Licensee MDPI, Basel, Switzerland. This article is an open access article distributed under the terms and conditions of the Creative Commons Attribution (CC BY) license (http://creativecommons.org/licenses/by/4.0/). 